\title{
From Female Labor Force Participation to Boardroom Gender Diversity
}

\author{
Renée B. Adams \\ University of New South Wales
}

\author{
Tom Kirchmaier ${ }^{1}$ \\ Manchester Business School
}

\begin{abstract}
The list of barriers to female representation in management is analogous to the list of barriers to female labor force participation. Accordingly, we examine whether low female labor force participation is the main reason few women hold seats on corporate boards using data from 22 countries over the 2001-2010 period. Using a novel country-level measure of female participation on corporate boards, we show first that the representation of women on boards across countries is actually worse than most surveys suggest. We then examine the extent to which female labor force participation and institutional and country-level characteristics are related to boardroom diversity. We find that labor force participation is significantly related to the representation of women on boards when part-time and unemployed workers are excluded. However, cultural norms, the presence of boardroom quotas and codes promoting gender diversity are also correlated with female representation. This suggests that economic and cultural factors may be important barriers to female career advancement, but that preferences may be less important. While quotas may overcome problems of discrimination, they may be too narrow a policy tool to address other causes of female underrepresentation in management.
\end{abstract}

First version: December 2012

\footnotetext{
1 Adams: Australian School of Business, University of New South Wales, FIRN and ECGI. renee.adams@unsw.edu.au . Kirchmaier: Manchester Business School \& Financial Markets Group, LSE. tom.kirchmaier@mbs.ac.uk. We thank our discussants Trond Randøy and Svetlana Taylor, and Jean-Paul Faguet for helpful comments. We also thank conference participants at the 2011 Copenhagen Diversity Conference and the 2012 Cardiff Corporate Governance and Investment Workshop for their insights. We thank Ben Moshirian, Min Park and Daniel Moevius for excellent research assistance. Adams thanks the Australian Research Council for financial support, Kirchmaier the AXA Research Fund.
} 


\section{Introduction}

Numerous surveys document the relative underrepresentation of women on corporate boards. In response, many countries are implementing policies designed to increase boardroom gender diversity. Since at least 1993, several countries have instituted diversity quotas for state-owned companies. ${ }^{2}$ Since Norway enacted boardroom gender quota legislation for listed companies in 2003, more and more policies target listed companies. Country-level policies take the form of either mandatory quotas or governance codes for listed companies that specifically identify gender as a factor boards must consider in appointment decisions. ${ }^{3,4}$ Other countries do not have formal policies but their major stock exchanges require that listed companies disclose their diversity policies with respect to gender. ${ }^{5}$ In a hotly debated move, the E.U. approved a draft law that sets an objective of $40 \%$ female nonexecutive directors on boards of listed companies across the 27 member states of the E.U. on November 14, 2012 (European Commission, 2012 a). However, we do not yet have a good understanding of the impediments to top executive positions for women. Thus, it is not clear that simply targeting the proportion of women in leadership positions, as all these recent policies do, will be effective at addressing the underlying causes of female underrepresentation in corporate leadership.

There are many potential barriers to female leadership. Most obviously, managers may not promote women because of taste-based or statistical discrimination. Male managers often perceive women as being less experienced than men (Doldor, Vinnicombe, Gaughan and Sealy, 2012), which in and of itself may lead to statistical discrimination. Lack of experience is a Catch-22 as women can never gain experience if they are not promoted. Culture may also be important. For example, Norris and Inglehart (2008) document that social norms are related to the representation of women in political leadership across countries. Similarly, Sanders, Hrdlicka, Hellicar, Cottrell, and Knox (2011) identify differences in perceptions of leadership "style" as an impediment to female advancement.

But demand side factors may also play a role. Almost all reports on the topic cite the costs of managing work and family as a major barrier. Bertrand, Goldin and Katz (2010) identify motherhood as the main factor leading to career disruptions and shorter working hours for a group of female MBA students from the University of Chicago. Differences in preferences and psychological factors may also be important (Pande and Ford, 2011). For example, if women are more risk-averse than men or shy away from competitive situations (Croson and Gneezy, 2009) they may be less likely to pursue high-profile careers.

\footnotetext{
${ }^{2}$ Austria, Denmark, Greece, Finland, Iceland, Israel, South Africa have quotas for state-owned companies.

${ }^{3}$ In addition to Norway, Spain, Iceland, Belgium, France and Italy have enacted quota legislation. Israel may also be considered to have a quota although it is minimal.

${ }^{4}$ Austria, Belgium, Denmark, Finland, France, Germany, Italy, Morocco, the Netherlands, Sweden and the UK have governance codes.

${ }^{5}$ Australia and New Zealand require the disclosure of gender-specific policies. The US requires only disclosure of general diversity policies.
} 
What is remarkable about the list of barriers to female leadership is that in many ways it is unremarkable. In their Handbook of Labor Economics article from 1999, Altonji and Blank (1999) discuss the role of preferences, discrimination and human capital as factors influencing female labor supply and labor market outcomes. Fernandes (2007) discusses the importance of culture and changing beliefs about women's role for female labor supply. In her 2010 chapter in the Handbook of Labor Economics, Bertrand focuses on psychological attributes, such as risk-taking attitudes, and differences in preferences between men and women as important determinants of labor market outcomes for women.

If the same factors influence whether or not women enter the labor force at all and whether or not they enter the boardroom, then it is not clear that policies in this area should target boards. Not only are quotas at the management level likely to be disruptive for companies (e.g. Bøhren and Staubo, 2012), but they may not necessarily be effective in the long run. For example, imposing a gender quota on boards in countries with relatively underdeveloped childcare services will automatically lead companies to try to increase the proportion of women on their boards to fulfill the quota. However, it need not lead to a large change in the number of women holding directorships. Instead, the same set of female directors that were in place before the quota may simply be sitting on a larger number of boards. If the costs of managing work-life balance are important deterrents to female representation in management, a more effective policy might target those costs directly.

But if the same factors influence whether or not women enter the labor force at all and whether or not they enter the boardroom, then an important question is whether increasing female labor force participation is sufficient to generate a larger pipeline of potential female executives or whether factors such as discrimination and culture still play a role conditional on female labor force participation. The purpose of this paper is to examine the relative importance of these factors for female corporate leadership. Because labor force participation, institutional and regulatory environments and culture change slowly over time, we examine the relative importance of these factors across countries.

Our sample consists of an unbalanced panel of 9,888 listed companies in 22 countries: Australia, Austria, Belgium, Bermuda, Canada, Denmark, Finland, France, Germany, Greece, India, Ireland, Italy, Luxembourg, the Netherlands, Norway, Portugal, Spain, Sweden, Switzerland, United Kingdom and USA. We obtain data for these countries over a ten-year time period from 2001 to 2010 from BoardEx. Boardex collects data on companies in 83 countries. To ensure our sample is representative, we restrict ourselves to country-years for which Boardex covers at least $70 \%$ of the total market capitalization of listed companies in that country and year.

Using this data set, we provide the first systematic evidence on the representation of women on boards of listed firms across countries and over time. While numerous surveys of boardroom gender 
diversity exist, they are often one-offs and not clearly representative of the general population of listed firms. This makes it difficult to compare statistics over time and across countries.

We first show that prior diversity surveys are potentially misleading. The representation of women is actually worse than most surveys suggest. The reason for this is that most surveys, such as the Catalyst Fortune 500 surveys in the US (e.g. Soares et al., 2010), focus only on large firms. Another problem is that most surveys focus on the average proportion of female directors at the firm level, which means they do not account for multiple directorships. Because we are interested in the representation of women in corporate leadership at the country-level, it is natural for us to focus on a measure that avoids counting the same individual more than once. This is the proportion of unique female directors in the set of all unique directors in a given country-year, a measure we call "Director Participation". Because men may also hold multiple directorships, it is not clear whether focusing on directorships instead of directors leads to an upward or downward bias. We show that it can go either way.

The differences between Director Participation in our sample and standard survey measures of the representation of women on boards can be striking. For example, the 2011 Davies Report for the UK (Davies, 2011) starts with the observation on page 3 that "In 2010, women made up only $12.5 \%$ of the members of the corporate boards of FTSE 100 companies. This was up from 9.4\% in 2004." In our data, the proportion of unique female directors on the boards of listed firms in the UK in 2004 was only $5.1 \%$ and in 2010 it was $6.5 \%$. While the magnitudes of Director Participation are low, they do show a clear upward trend over time. For example, the proportion of unique female directors in Ireland was $3.1 \%$ in 2001 and $7.9 \%$ in 2010. Moreover, Director Participation generally becomes larger when we restrict our sample to large firms in each country.

We then turn to an analysis of country-level and institutional factors that are related to Director Participation. We examine Director Participation for non-executive and executive directors separately because most policies target non-executive board positions. In addition to measures of female labor force participation, we examine the importance of country-level measures of family-friendliness, such as taxes and social security contributions over income. We use country-level measures of the gender gap in wages as an economic measure of discrimination and Inglehart and Welzel's (2005) Traditional/Secular and Survival/Self-Expression value scores as measures of culture. We also examine the importance of different types of country-level policies concerning boardroom gender diversity. In our regressions we control for the prevalence of family firms and co-determination as they are plausibly related to the representation of women on boards, but in different roles than the typical corporate director. To address potential endogeneity concerns in these regressions we lag labor force participation by 10 years, which is the natural limit imposed by the poor quality of economic 
indicators in the 1980s. We also use instrumental variable regressions to address concerns about omitted variable bias.

We find that labor force participation is positively and significantly correlated with non-executive Director Participation, but only if we exclude part-time workers from labor force participation. In our benchmark model, a one standard increase in full-time labor force participation is associated with a 2.6\% increase in Director Participation. We consider this effect economically large. This suggests that policies that promote full-time employment by women are important for generating a pipeline of women who eventually end up in top corporate positions. For the US, Bertrand (2009, p. 127) argues that "a continuous commitment to the workforce is a sine qua non condition to reach the top in corporate America". Our results suggest this holds true outside of the US as well. But other factors also play a role, even after accounting for full-time labor force participation. Policies matter, even when they are voluntary; the existence of corporate governance codes is positively correlated with Director Participation. Measures of discrimination and culture also appear to matter. In most specifications, the effect of culture is almost as large as the effect of full-time labor force participation. This suggests that even when they are employed full-time, women may face barriers to career progression.

While female labor force participation has some explanatory power for executive Director Participation, the magnitude of the effect is roughly one third of the effect for non-executive directors. Little else seems to matter except for taxes and social security contributions over income and the existence of quotas for state-owned companies. It is possible that there are simply too few women in executive positions across countries to generate meaningful variation in the data.

Our results suggest that preferences may be relatively unimportant in explaining the underrepresentation of women on boards. If preferences were important, then countries with quotas and codes would have difficulty in finding women to accept board positions. But this does not seem to be the case. Thus, quotas and governance codes seem to be effective at solving problems of discrimination. However, it is not clear whether they can be effective on their own. The fact that few of the factors we consider are related to executive Director Participation suggests that women have a long way to go in terms of transitioning from being an external board member to running their own boards. Board-level policies may need to be complemented by policies that help women at all levels of the corporate hierarchy combine work with family. Furthermore, if gender quotas induce negative attitudes towards women, they are unlikely to be effective.

Our paper complements both the literature on female labor market outcomes as well as the governance literature. With the notable exception of Bertrand and Hallock (2001) most of the labor 
literature does not examine women in top management. ${ }^{6}$ We believe studying top managers is interesting for several reasons. First, the fact that women fill board positions to a greater extent in some countries than others suggests that, cultural differences aside, a subset of the population of women may not be so different from men in their preferences and psychology. As Betrand and Hallock (2001) point out, men and women in top management are likely to be similar in their career ambitions and motivations. Most of the literature on female work outcomes is concerned with the average woman in the population, but analyzing the top management level highlights that there may be significant variation in preferences or psychological factors, such as risk-aversion, in the population.

Second, women can achieve a top management position only if they have been in the work force long enough. Examining the relative underrepresentation of women at the board level highlights the fact that women often drop out of the labor force. To better understand women's labor force outcomes, it is important to understand why.

One of the main reasons why policy makers are concerned with the relative underrepresentation of women on boards is because they argue there is a business and economic case for more women on boards. The European Commission (2012 b, p. 10) states that

"One of the ways of improving Europe's competitiveness is the equal representation of women and men in economic decision-making positions, which contributes to a more productive and innovative working environment and helps improve performance. In addition, there is an increasing body of research showing that gender diversity pays off and that there is a positive correlation between women in leadership and business performance."

Similarly, the Davies Report (Davies, 2011, p. 3) says "The business case for increasing the number of women on corporate boards is clear." However, we believe the evidence that greater boardroom diversity improves company performance is not at all clear. Using firms from the U.S., Adams and Ferreira (2009) show that the average effect of boardroom gender diversity on firm performance is not positive. Diversity adds value to some firms, but not all. Ahern and Dittmar (2012) show that the market reaction to the Norwegian gender quota was negative and Matsa and Miller (2011) show that the Norwegian quota may have hurt short run profits due to fewer layoffs in firms most affected by the quota. Bøhren and Staubo (2012) show that roughly half of the firms exposed to the Norwegian gender quota changed their organizational form to avoid it.

The literature also often ignores the fact that women who sit on boards before quotas may be different than women who sit on boards after quotas. For example, Adams and Funk (2012) document that female corporate directors in Sweden have fewer children than women in the population. If

\footnotetext{
${ }^{6}$ Some papers do examine women in more senior positions. For example, Black and Juhn (2000) examine professional women. Other papers examine lawyers, politicians and academics (see the review in Bertrand and Hallock, 2001).
} 
women with more children end up sitting on boards as a result of quotas, but there is little institutional support for families so that these women are subject to greater demands on their time than before, then it is not clear that company performance should improve with their presence. A better understanding of the barriers to female corporate leadership contributes to the existing governance literature on gender diversity because it highlights the situations when diversity has the potential to add value at the company level.

Our paper is structured as follows. We discuss the country-level characteristics we relate to director participation in Section II. In Section III, we describe our sample selection process and data. In Section IV, we provide a general picture of the representation of women in director positions across countries and over time. In Section V, we examine the relationship between non-executive Director Participation and country-level variables. We replicate this analysis for executive Director Participation in Section VI. We conclude in Section VII.

\section{Country-level Characteristics related to the Representation of Women on Corporate Boards}

We consider five sets of country-level variables in our analysis. We choose these variables because we believe they are likely to represent general conditions that are either barriers, or are conducive, to female corporate leadership.

Our main variable of interest is female labor supply. If a large portion of the female population is working, then more women should eventually enter corporate boardrooms if there are no other barriers to female leadership. We measure labor force participation in two ways. Our first measure, Classic LFP, is the proportion of women working as a fraction of the female population. Our second measure, Female Economic Participation, is the proportion of women working as a fraction of the employed population. The motivation for the second measure is that it is more closely related to our dependent variable, Director Participation, which is the proportion of female directors in the director population.

In contrast to much of the literature on female labor supply, we calculate these measures with and without part-time and unemployed workers. We believe it is unlikely that part-time workers will have the skill set needed to obtain a directorship. Similarly, unemployment represents a career disruption that may be difficult to overcome. To address the concern that Director Participation may lead to more female labor force participation, we lag our labor supply measures by the maximum number of years that is feasible given the quality of international economic indicators-10 years.

The next set of variables of interest relate to how family-friendly countries are. The more familyfriendly a country is, the easier it should be for women to manage both work and family and the less 
likely it should be that they drop out of the labor force. It is difficult to get good data on direct measures of family-friendliness, for example maternity leave and childcare benefits, which are comparable across countries and that vary over time. For this reason, we use the 10-year lagged birthrate in a country as an indirect proxy for family-friendliness at the time when it should have affected a female director's career trajectory the most, i.e. near the beginning of her career. Holding female labor force participation and economic development constant, we expect birthrates to go up only if the provision of services to families increases. We also use data on lagged tax and social security contributions over income as a measure of family-friendliness, because government spending on services that benefit families is likely to be higher in countries with greater taxation. In robustness checks, we also use more direct measures of government spending on families that are cross-sectional.

To proxy for levels of discrimination in the labor market for women, we use a measure of the gender wage gap. If women consistently earn less than men for equal work, it is plausible that they also face barriers to advancement that would prevent them from achieving senior management positions. It is difficult to obtain data on the gender wage gap across all countries in our sample. For this reason, we use a qualitative variable on wage equality for similar work, Wage Equality, from the World Economic Forum's Executive Opinion Survey (Hausman, Tyson and Zahidi, 2010). This measure receives the largest weight in the "economic participation and opportunity" subindex of the World Economic Forum's Gender Gap Index. In robustness checks, we also use estimates of the skilled gender wage gap across countries from Olivetti and Petrongolo (2011), although we lose observations due to incomplete coverage of countries in our sample.

A growing literature argues that culture has an important role to play in explaining female work outcomes. Goldin (1991) argued that female labor force participation increased substantially after World War II because it led to changes in attitudes towards working women. Fernandez (2007) and Fernandez and Fogli (2009) also argue that culture matters and use characteristics of the countries of origin for US immigrants, such as female labor supply, to proxy for culture. Alesina and Giuliano (2010) and Alesina, Giuliano and Nunn (2012) examine the role of family values and attitudes towards women's work for female labor supply using data from the World Value Survey (WVS).

Culture may also have a role to play in the evolution of women's careers. If family values are strong then it may be difficult for women to accept more demanding positions. Women may also be passed over for promotion because of the perception that women are not natural leaders. We examine the impact of culture by using Inglehart and Welzel's (2005) country-level Traditional/Secular and Survival/Self-Expression value scores for the WVS.

Inglehart and Welzel (2005) argue that the Traditional/Secular value dimension reflects the contrast between societies in which religion is very important and those in which it is not. More traditional societies emphasize the importance of parent-child ties and deference to authority, along 
with absolute standards and traditional family values, and reject divorce and abortion. Thus we expect more traditional countries to have lower representation of women on boards.

Inglehart and Welzel (2005) link the Survival/Self-Expression value dimension to the transition from industrial society to post-industrial societies. In developed economies priorities shift from an emphasis on economic and physical security toward subjective well-being, self-expression and the quality of life. Because work is one way in which self-expression can occur, we predict that more women will sit on boards in countries with greater self-expression values.

The advantage of using these scores rather than individual items from the WVS as in Alesina and Giulano (2010), Alesina, Giuliano and Nunn (2012) and Olivetti and Petrongolo (2011) is that they account for multiple dimensions of culture. Inglehart and Welzel (2005) document that these dimensions explain over 70 percent of the cross-cultural variance of more specific value scores in the WVS. Moreover, the country-level coverage of these scores is more complete than for individual items in WVS. In robustness checks, we also use some individual items in the WVS, but we lose observations due to incomplete coverage across countries.

Fernandez and Fogli (2009) argue that labor force participation and fertility rates reflect the economic and institutional environment women face, as well as cultural beliefs about the value of women's work. Thus, labor force participation is in and of itself a proxy for family-friendliness, discrimination and values. If our proxies for these conditions matter for female corporate leadership even after we control for labor force participation, then it would appear that the link between entering the workforce and significant career progression is not automatic for women.

Our final group of variables relate to policies that target female board representation. We examine the effect of two types of policies that we tabulate at the country-level in Table I. The first set of policies consists of mandatory quotas for listed companies and quotas in state-owned companies. While it is well-known that mandatory quotas increase the average proportion of women on boards, it is not clear how these quotas translate into changes in the proportion of women in the director population. Because of multiple directorships, a $40 \%$ gender quota need not lead to a $40 \%$ increase in Director Participation. Examining the magnitude of the effect of quotas on Director Participation is interesting because it tells us something about the demand for directorships by women in the population. If a large quota translates into a large change in Director Participation, then this suggests that the demand for directorships in the female population is strong and that preferences are not important barriers to corporate leadership.

-Insert Table I about here-

The second type of policy consists of country-level governance codes for listed companies. We consider a governance code to have a board-level gender diversity recommendation if it mentions that gender should be considered by the board in its appointment process for new directors. While these 
codes are not mandatory, it is still possible that they influence appointment decisions. It is plausible, for example, that they have a similar effect as diversity disclosure rules. Adams, Nowland and Grey (2011) show that the ASX diversity disclosure requirements led to a significant increase in the number of female directors that were appointed in Australia. Because all such disclosure policies occurred after the end of our sample period, we do not consider the effects of such disclosure policies separately.

As control variables in our regressions, we include 10-year lagged per capita gross national income (GNI) as a measure of economic development. To isolate factors specific to the director labor market, we also control for the proportion of our sample firms that are family firms and a dummy for countries with co-determination laws. It is plausible that countries with many family firms have more women on boards because they are members of controlling families. It is also plausible that countries with co-determination have more women on boards because women exhibit greater concern for employee welfare than men and may be more likely to represent employees. For example, Adams, Licht and Sagiv (2011) show in a sample of Swedish directors that even when they are not employee representatives, female directors are more stakeholder-oriented (as opposed to shareholder-oriented) than male directors. Matsa and Miller (2011) show that boards most affected by the Norwegian gender quotas laid off fewer workers and Matsa and Miller (2012) argue that labor hoarding may be a characteristic of female leadership style. Finally, we control for the lagged fraction of women in higher education. Eckstein and Lifshitz (2011a) estimate for the US that a large portion of female labor supply can be explained by education (33\%). Because the correlation between education and labor force participation is generally positive across countries (Psacharopoulos and Tzannatos, 1989), this is likely to be true in other countries as well. Thus, controlling for education helps ensure that our coefficients on labor force participation are not simply picking up the effect of education on Director Participation.

\section{Data}

We describe our sample construction in Section A. In Section B, we provide summary statistics for our data set and discuss its coverage.

\section{A. Data Sources and Measurement}

Our starting sample consists of the entire Boardex database from 2000-2011 as of September 2011. BoardEx contains data compiled by the UK-based firm Management Diagnostics Limited on boards of publicly traded companies. Our base sample consists of an unbalanced panel of data on 16,129 firms and 136,950 unique directors in 83 countries. 
One of the shortcomings of BoardEx is the lack of data on the population of firms it covers. This makes it difficult to determine how representative its coverage is. To determine what fraction of each country's set of listed companies is covered by Boardex, we match it to the entire CapitalIQ database. CapitalIQ claims to achieve $99 \%$ coverage of all listed companies in the world. While we cannot verify that claim, we do succeed in matching all firms in BoardEx to CapitalIQ. We also observe that CapitalIQ covers substantially more listed firms than BoardEx. In 2010 for example, CapitalIQ covers 32,786 listed companies while BoardEx covers only 8,224. Over the entire sample period, CapitalIQ covers 41,416 listed firms versus 10,485 listed companies in BoardEx. This satisfies us that CapitalIQ is an acceptable reference database for BoardEx.

Using financial data from CapitalIQ, we calculate a measure of a country's stock market capitalization in a year as the sum of the market capitalizations of all firms in CapitalIQ for that country and year. We then aggregate the market capitalization for firms in Boardex and show the percentage of the total market capitalization they represent in Table II. For a county-year to enter our final sample, we require that Boardex covers at least $70 \%$ of market capitalization in that country and year. We chose this threshold because it balances concerns about coverage with concerns about sample size. ${ }^{7}$ We also require both CapitalIQ and BoardEx to cover at least 10 listed companies per country-year. We drop the year 2000 because of its low coverage, and the year 2011 as it is incomplete. We also drop companies from the British Virgin Islands, Russia, and Cyprus, as we have a representative sample for these countries in BoardEx for one year only.

-Insert Table II about here-

With these restrictions, our final sample consists of an unbalanced panel of 9,888 listed firms in 22 countries stretching over a ten-year time period from 2001 to 2010 . Overall, we base our analysis on a total of 55,899 firm-year observations for that period. At the director level, we follow 90,208 unique directors, of which 82,911 are male, and 7,297 are female. The dataset is complete in respect to gender. The sample covers 42 sectors.

We calculate Director Participation as the fraction of unique women in the population of unique directors in a county and year. We calculate these measures separately for executive directors (EDs) and non-executive directors (NEDs), as most policy initiatives concerning boardroom gender diversity implicitly target NEDs. ${ }^{8}$ For comparison purposes, we also calculate traditional measures of boardlevel gender diversity (Board Diversity) as the average fraction of women on boards at the firm level.

\footnotetext{
${ }^{7}$ As a robustness check, we also examined an $80 \%$ with similar results although a loss in statistical significance due to the smaller sample size.

${ }^{8}$ In these separate measures, the denominator is the population of unique EDs or NEDs in a country-year, respectively. If a woman holds both positions, she appears in both measures, but only once. Thus, Director Participation for EDs eliminates multiple executive positions held by the same person, Director Participation for NEDs eliminates multiple non-executive positions held by the same person and Director Participation for the whole board counts each person only once.
} 
We source all firm-level financial data from CapitalIQ. We obtain country level measures of labor market participation, the number of full- and part-time employees, ${ }^{9}$ the gross national income per capita and tax, the birthrate and tax and social security contributions over income and the fraction of women in higher education from Euromonitor. As more direct measures of government services to families, we obtain 2007 data on service and tax break components of public spending (Family Benefits-Services and Family-Benefits-Tax breaks) as a percent of GDP from the OECD family database. We convert inflation-adjusted monetary indicators into USD at 2011 exchange rates.

Ideally, we would like to measure conditions affecting a female director's career trajectory at the time when they are likely to matter the most, i.e. near the beginning of her career. As the international coverage of economic indicators is poor in the 1980s, a 10 year lag is the natural limit for most of these variables.

We obtain data on the gender wage gap in the World Economic Forum's Executive Opinion Survey from the World Economic Forum's (WEF) 2010 Global Gender Gap Report (Hausman, Tyson and Zahidi, 2010). This measure is a score on a scale from 1 to 7 where 1 represents the worst outcome and 7 the best. The 2010 report provides data from 2006 to 2010 . Because the response rate to the surveys varies over the years, we average the responses over time to construct our measure of the wage gap (Wage Equality). As an alternate measure of the wage gap, we use the country-level estimates of the skilled gender gaps in wage bill shares from Olivetti and Petrongolo (2011, Table 2, column 2). ${ }^{10,11}$

We source the most recent data on the 5-wave value scores according to Inglehart and Welzel (2005) from the World Value Survey. ${ }^{12}$ We also use individual items to measure country-level cultural preferences from waves 4 (1999-2004) and 5 (2005-2007) of the World Value Survey (WVS). We focus on three variables: (1) d057 - Being a housewife is just as fulfilling as working for pay (Women Housewife) (2) a029 - Independence is an important child quality to be learnt at home (Child Independence) and (3) e233- Democracy: Women have the same rights as men (Women's Rights).

Alesina and Giuliano (2010) and Olivetti and Petrongolo (2011) use Women Housewife as a measure of the perceived role of women in society. Women Housewife can take values from 1 'strongly agree' to 4 'strongly disagree'. We reverse the ordering so that higher values measure greater agreement.

\footnotetext{
${ }^{9}$ According to the International Labor Organization (1997), the definition of part-time workers varies from country to country, and is typically based on a time-threshold, and/or self-assessment. This makes it difficult to compare levels of part-time work across countries. As we are interested in whether female employment is perceived as full or part-time work within countries, we do not believe that this affects the interpretation of our results.

${ }^{10}$ We also used Blau and Kahn's (2003) estimate of gender wage gaps for full-time workers with similar results.

${ }^{11}$ Olivetti and Petrongolo's (2011) estimates are based on data from men and women aged 25-54, excluding military, students, and self employed for 1994-2001, except for Canada (1997-2004), Finland (1996-2001) and Austria (1995-2001) from the CPS, Canadian LFS, and ECHPS.

${ }^{12}$ The data in our sample is either from wave 4 or wave 5 of the WVS. The data is available here.
} 
One problem with Women Housewife is that it may simply reflect occupational patterns in a country rather than cultural values. If respondents do not know whether staying at home is fulfilling or not, they may infer that it is simply because female labor force participation rates happen to be low in a country. ${ }^{13}$ For this reason, we also examine Child Independence and Women's Rights, which are not tied directly to any observable outcome.

We believe it is intuitive that women may be more likely to focus on their own careers in countries that place a high value on child independence. Child Independence is the coding of the following question: "Here is a list of qualities that children can be encouraged to learn at home. Which, if any, do you consider to be especially important? Please choose up to five." Respondents can choose from 17 qualities including 'independence', 'manners', 'politeness', 'hard work', 'honesty' and 'faith'. Child Independence takes on the values 1 if 'independence' is mentioned as 'important' or 0 'not mentioned'.

Women's Rights is the response to the following question: "Many things may be desirable, but not all of them are essential characteristics of democracy. Please tell me for each of the following things how essential you think it is as a characteristic of democracy. Use this scale where 1 means "not at all an essential characteristic of democracy" and 10 means it definitely is "an essential characteristic of democracy": Women have the same rights as men." Because Women's Rights measures fundamental beliefs about equality between men and women, we expect that it should be positively related to the representation of women on boards. We average all WVS variables across all respondents in a country for both waves and match data from 2001-2004 to the wave 4 average and data from 2005-2010 to the wave 5 average.

We collect data on gender quotas, state-owned company quotas and corporate governance codes from a variety of sources. We use European Union (2012) and Paul Hastings (2012) to identify countries with policies targeting gender diversity on boards. We then search for the original source documents on the internet. We use the ECGI code database to identify the first time a country's code mentions that gender must be considered by the board. We create a dummy variable for each type of policy that is one in the year the policy was passed, and all years after.

It is difficult to find statistics on the prevalence of family firms across all countries in our sample. Thus, we generate a within-sample measure of the prevalence of family firms. We assume that family firms will be characterized by greater ownership concentration than other firms, as well as a higher propensity to have family members with the same last name on the board. To proxy for ownership concentration, we obtain historic data on the proportion of closely-held shares (FF_SHS_CLOSELY_HELD) from Factset. These shares include shares held by officers, directors

\footnotetext{
${ }^{13}$ We believe the same issue holds for the response to "When jobs are scarce, men should have more right to a job than women" used in both Alesina and Giuliano (2010) and Olivetti and Petrongolo (2011) as a measure of gender role attitudes. The responses could be reflecting labor force participation rates by men and women rather than intrinsic values.
} 
and their families, shares held in trust and shares held by pension plans and $5 \%$ blockholders. After accounting for missing data, the coverage of Factset for our sample firms varies from $75.7 \%$ for Norway in 2001 to $100 \%$ for Finland and Portugal in various years. For missing in-between firm-year observations we linearly interpolate the missing values, and for missing values in 2009 and 2010 we linearly extrapolate them. We report the average coverage of Factset for our sample in Table II.

We consider a firm to be a family firm if the proportion of closely held shares is greater than $20 \%$ and any two board members share the same last name in a given year. We treat hyphened names common in Latin American countries - as two separate names and assume that the firm is a candidate for a family firm if any of the two names match with another name on the same board and year. By considering both ownership and name-matching, we account for the inherent under-reporting of matching that may occur because women may change their names after marriage. If a firm does not have ownership data available in Factset, we classify firms as family firms based on name matching alone. Our measure of the proportion of family firms in each country-year is the country-level average of a family firm dummy. In robustness checks we also use data on the prevalence of family firms from Faccio and Lang (2002, Table 3), but our sample drops substantially because they only cover Western European countries.

Finally, we code a variable that is equal to 1 if the country has co-determination laws in place and 0 otherwise (see Table I). We obtain information on these laws from Kluge and Stollt (2006) and Osterloh, Frey and Zeitoun (2011).

\section{B. Summary Statistics}

In Panel A of Table III, we provide means of all variables in our data set by country. In Panel B, we provide sample-level summary statistics for all variables including our policy dummies. For the sake of brevity, we summarize variables we use primarily in robustness checks in the Appendix. Because Norway passed its gender quota legislation towards the beginning of our sample period, we conduct our main analysis without Norway. To be able to assess the economic significance of our coefficient estimates, we exclude Norway from Panel B.

-Insert Table III about here-

While on average $39.6 \%$ of women are working and women represent $42.5 \%$ of the workforce, many female employees work only part-time. If we exclude part-time and unemployed workers from the numerator, the representation of women drops to $27.7 \%$ of the workforce. If we also exclude parttime and unemployed workers from the denominator, the representation of women becomes $35.7 \%$ of full-time employment. 
Across countries, women comprise $8 \%$ of the population of directors, mostly in non-executive positions. They make up $9 \%$ of the population of NEDs and only $4 \%$ of the population of EDs. We turn to a more extensive discussion of female board representation in the next Section.

\section{Female Board Representation}

In Table IV, we show aggregate measures of Director Participation across countries and over time for the country-years for which we deem Boardex to have adequate coverage of the entire market capitalization $(\geq 70 \%)$. For most countries, there is a clear time trend with rising levels of Director Participation over time. But there is still considerable variation across countries in the levels of Director Participation. For example, in 2010 India has only 5.2\% Director Participation, while Norway has $37.1 \%$. One might think that India's low numbers can be attributed primarily to economic development and Norway's high numbers to the Norwegian gender quota. However, in 2010 both Austria and Italy had similar levels of Director Participation as India, 5.9\% and 5.5\%, and Norway had high levels of Director Participation relative to other countries even before the quota. In 2002, the year before the Norwegian quota legislation, only Sweden had higher levels of Director Participation. Thus, the role of country-level characteristics and policies in explaining differences between countries is not immediately obvious.

-Insert Table IV about here-

-Insert Table V about here-

To compare Director Participation to traditional measures of female board representation, we reproduce the same table with the average fraction of women on boards (Board Diversity) instead of Director Participation in Table V. While the numbers generally look quite similar, some countries (e.g. Italy) have lower numbers of Director Participation than Board Diversity whereas others have higher levels of Director Participation (e.g. the UK and the US). To illustrate that it is not obvious how greater firm level diversity translates into the proportion of unique women in director positions, we examine the role of multiple directorships and board size in Table VI.

-Insert Table VI about here-

In columns 1 and 2, we reproduce Board Diversity for 2010 from Table V and Director Participation for 2010 from Table IV. In column 3, we provide an estimate of the "gender gap" in multiple directorships. For each country, we regress the number of (within-sample) board seats individuals hold in 2010 on a female dummy. The coefficient on the female dummy is our estimate of the "gender gap". It is statistically significant for Canada, the UK and the UK, where women hold more directorships than men, and France, Germany, Portugal and Switzerland, where women hold 
fewer directorships. However, holding more directorships alone does not explain differences in Director Participation and Diversity. The relation also depends on firm-level board size, which influences the total number of director positions in the country. In column 4, we examine the proportion of female directorships (total number of board seats held by women/total number of board seats). We now observe that the gender gap in multiple directorships explains the difference between the proportion of female directorships and Director Participation. In countries in which women hold more directorships, the proportion of female directorships is larger than Director Participation. In countries in which women hold fewer directorships, the proportion of female directorships is lower than Director Participation. This simple analysis suggests that targeting firm-level diversity may not always translate into greater Director Participation because of the role of firm-level governance and multiple directorships.

However, these two factors do not explain why Board Diversity in Table V is generally lower than often-cited numbers for Board Diversity in the literature. We argue that the apparent downward bias in our numbers can be explained by the fact that we have a more representative population of firms than studies that focus primarily on large firms. We provide evidence for this argument in the remainder of Table VI, where we compare our numbers to other numbers in the literature.

While numerous surveys of board diversity exist, we choose to compare our data to only two of these. The first is the GovernanceMetrics International (GMI) (2010) report because it covers most of the countries in our sample and is a widely-used survey (e.g. Catalyst, 2012). The drawback of using the report as a benchmark is that GMI calculates statistics for companies it provides investment research for and it is not clear which companies are in the data. Since we argue that the representation of women looks different the more representative the sample, it is nevertheless useful to compare our numbers to the GMI sample.

The second set of data we examine is the European Commission's gender balance in decisionmaking database for 2010 because this database is the main data source underlying the EU's draft law concerning boardroom diversity (European Commission, 2012 a) as well as other European Commission reports on this issue (e.g. European Commission report, 2012 b). This data set consists of board-level gender diversity data for the largest (primary blue-chip index members) listed companies in each country (maximum 50 per country).

We replicate the GMI numbers and European Commission numbers in columns 5 and 6 . We provide the number of firms in the GMI, European Commission and our 2010 sample in columns 7-9.

Eight countries have higher levels of Board Diversity in our sample than in the GMI sample, but the rest all have higher levels of Diversity in the GMI sample. Moreover, these differences tend to be large at times. For example, according to GMI the Netherlands and Germany had 13.7\% and 10.46\% women on boards in 2010, respectively. In our sample, they have $7.4 \%$ and $6 \%$ women on boards. 
Five out of 15 countries appearing in both our sample and the European Commission's data have larger levels of Board Diversity in our sample. The rest all have smaller levels of diversity in our sample. Again, the differences are at times large. For example, in the European Commission's data, firms in the United Kingdom and Denmark have on average 13\% and 18\% female directors. In our data average diversity is $6 \%$ and $12.5 \%$, respectively.

As is evident from columns 7-9, the number of firms in our sample is much larger than in the GMI and EU samples. Because it is plausible that GMI primarily covers large companies in each country, we sort companies in our sample by market capitalization and choose the same number of firms as in the GMI sample from the top of the list. We calculate Board Diversity in this sample of largest firms and report it in column 10. For comparison purposes, we also report Director Participation, the "gender gap" in directorships and the proportion of female directorships in columns 10-13. Board Diversity in this restricted sample of large firms is smaller than Board Diversity in our full sample for all but three countries (Italy, Portugal and Greece). When we compare our statistics for large companies to the GMI numbers, we see that the distance between the GMI Diversity and our large company Diversity numbers decreases on average. The average distance between GMI Diversity and our full sample Diversity is $2.61 \%$. The average distance between GMI Diversity and large company Diversity is $1.8 \%$. While these numbers may appear small, they are large relative to the mean of Diversity in Table III, Panel B (7.8\%). Consistent with the comparisons to the EU data, this suggests that larger companies have more women on their boards. By focusing primarily on large companies, popular statistics overstate the representation of women.

\section{Country-level Characteristics and Director Participation- The Case of NEDs}

Our first objective in relating country-level factors to Director Participation is to examine the role of lagged female labor force participation. Because the representation of women is greater in nonexecutive positions, we focus first on NEDs. We analyze executive directors in Section VI. In Table VII, we show the output of regressions of Director Participation on labor force participation using data on all countries except Norway and Bermuda. We lose Bermuda because of missing data on labor force participation. We exclude Norway to ensure our results are not be driven by the fact that Norway is an outlier in terms of Director Participation. We show results with Norway in our robustness checks.

The columns in Table VII vary according to the measure of labor force participation we use. We adjust standard errors for heteroskedasticity and within-country correlation. All regressions in Panel A include all controls we describe in Section II, as well as year dummies. To isolate the discussion of 
female labor force participation, we do not report the coefficients on control variables until Table VIII. The regressions in Panel B do not include any controls.

-Insert Table VII about here-

In column 1, we use Classic LFP as our measure of female labor force participation. In column 2, we adjust the numerator by excluding part-time workers. In column 3, we use Female Economic Participation as our measure of female labor force participation. In column 4, we exclude part-time and unemployed workers from the numerator. In column 5, we also exclude part-time and unemployed workers from the denominator, so that the measure in column 5 is full-time female employment over full-time employment.

The first thing to note from comparing Panel A to Panel B is that labor force participation is always statistically significantly correlated with Director Participation in Panel B, but not in Panel A. Moreover, the magnitudes of the coefficients in Panel A are at times substantially smaller. In column 1, for example, the coefficient on Classic LFP drops from 0.372 (significant at the 1\% level) in Panel $\mathrm{B}$ to 0.074 (not significant at conventional levels) once our controls are included. This pattern is consistent with the argument that female labor force participation reflects the economic, institutional and cultural environment women face and highlights the importance of controlling for these factors separately to better identify the direct effect of labor force participation.

When we compare coefficients across columns in Panel A, we observe that neither the coefficients on Classic LFP nor the coefficient on Female Economic Participation are statistically significant. However, labor force participation is significantly correlated with Director Participation once we exclude part-time (and unemployed) workers from the numerator (and denominator). Moreover the magnitudes of the coefficients increase and become economically large. A one standard deviation increase in female full-time economic participation (as in column 5), leads to a 2.6\% increase in Director Participation which is large relative to the mean of $9 \%$ of NED Director Participation and represents one half of the standard deviation of NED Director Participation. This pattern suggests quite strongly that a pre-condition for greater Director Participation by women is greater full-time employment by women.

But is full-time female employment sufficient for Director Participation? If so, we would expect the control variables to have little explanatory power once we control for female full-time economic participation. We examine the relationship between the controls and Director Participation in more detail in Table VIII. We regress Director Participation on female full-time economic participation and different sets of controls. All regressions include year dummies and have country-level clustered standard errors. Column 1 is our baseline specification with controls for codetermination, economic development, the prevalence of family firms and the fraction of women in higher education. In column 2 , we add our proxies for family friendliness. We add our proxy for wage equality in column 
3. Column 4 includes our measures of culture and column 5 includes the policy dummy variables. The specification in column 5 is the same as the specification in column 5 of Table VII and is our benchmark model.

Few of the coefficients on the baseline controls are statistically significant. Although codetermination has the expected positive sign across columns, it is only significant in column 1 . In contrast to our expectations, the coefficient on family firms is negative, although not always significant. The coefficient on the fraction of women in higher education is also negative except in column 5 .

However, several of the coefficients on the non-baseline variables are statistically significant. The coefficient on Tax \& Social Security is positive and significant at the $5 \%$ level and the coefficient on Traditional vs. Secular Values is positive and significant at the $1 \%$ level. In column 5, the coefficient on Quota and Corporate Governance Code are positive and significant. In column 6, we multiply the coefficient estimates in column 5 by the standard deviations of the variables to better compare the magnitudes of the different variables. A one standard deviation increase in Tax \& Social Security leads to a $0.9 \%$ increase in Director Participation, which is not large as compared to the effect of Fulltime Economic Participation. But a one standard deviation change in Traditional vs. Secular Values has a comparable effect, 2.5\%. Quotas and governance codes are associated with a $4.6 \%$ and $3.3 \%$ increase in Director Participation. ${ }^{14}$

We examine whether our results are driven by specific countries in Table IX. To ensure that high levels of birthrates in India are not affecting the results, we replicate the specification in column 5 of Table VIII after excluding India and report it in column 1. The coefficient on birthrate does indeed change sign, and becomes insignificant. All the variables whose coefficients were significant in Table VIII, column 5 remain statistically significant and of a similar magnitude. However, some variables whose coefficients were not significant now become significant, most notably the fraction of women in higher education and GNI/Capita that are both positively related to Director Participation in this sub-sample.

Because the US is likely to have a large population of part-time workers, we exclude the US in addition to India and Norway in column 2. The results are very similar to those in column 1 . In column 3, we add back in all countries including Norway. The results are very similar to those in Table VIII, column 5, except that now the coefficient on Quota has increased from 0.046 to 0.081 . We conclude that some factors seem to be important for Director Participation in all countries, namely female full-time economic participation, the level of taxes, measures of discrimination (Wage Equality), measures of culture and policies. The fraction of women in higher education, the birthrate

\footnotetext{
${ }^{14}$ Given that we exclude Norway here, the only country with quota legislation in our sample period is Spain.
} 
and economic development are not robust to including India. This suggests that career paths in India may be different than in more developed countries.

In Tables X and XI, we examine the sensitivity of our results to measurement error. We replicate the specification in column 5, Table VIII and substitute alternate measures for key variables in each column. In some cases our sample size decreases substantially (notably in column 2) because we could not obtain data on all countries in our sample. Moreover, all of the alternate measures are crosssectional, which means there may be less variation in the data in these specifications.

-Insert Table X about here-

In column 1, we use the estimate of the skilled labor pay gap from Olivetti and Petrongolo (2011) instead of Wage Equality. The sign is negative, which is consistent with the estimates for Wage Equality as a greater skilled pay gap means less wage equality. In column 2, we use the estimates of the prevalence of family firms from Faccio and Lang (2006) instead of Fraction of Family Firms. The sign is negative, consistent with our previous results. In column 3, we use Family Benefits-Services instead of Tax \& Social Security as a direct measure of services families receive from the government. The coefficient is positive and statistically significant, consistent with the idea that government support for families is important for women to remain in full-time positions long enough to advance their careers. The fact that the coefficient on Family Benefits-Tax breaks is insignificant in column 4 suggests that direct service provision to families is more important than tax breaks.

In Table XI, we examine alternate measures of culture using individual items from the WVS. We exclude Norway in these specifications, as Norway may be an outlier in attitudes towards women. In column 1, we use Women Housewife instead of Traditional vs. Secular Values and Survival vs. SelfExpression Values. The coefficient is negative and significant at the $5 \%$ level consistent with the idea that the more people believe that women's role is at home, the lower Director Participation will be. In columns 2 and 3, we use Child Independence and Women's Rights as measures of culture. In column 4, we include both Women Housewife and Child Independence as we have the same number of observations on both measures. Both Child Independence and Women's Rights are individually positively and significantly correlated with Director Participation at the $1 \%$ level. Column 4 suggests that Women's Rights may be a more precise measure of attitudes towards women than Women Housewife.

-Insert Table XI about here-

In general the coefficients on our explanatory variables are similar across tables in terms of signs and statistical significance with two exceptions. Fraction of family firm is positive and significant at greater than the $10 \%$ level when we use the individual items from the WVS, whereas before the coefficient was always negative. Codetermination also shows up as being highly statistically significant in these regressions. This suggests two hypotheses. Either the effect of family firms and 
codetermination is not robust or the individual measures of values we use are not sufficient to capture cultural attitudes. We believe the latter is the case as the correlation between Fraction Family Firms and Traditional vs. Secular and Survival vs. Self-Expression is -0.234 and -0.556 respectively. Thus family firms appear to be more prevalent in more traditional societies and less-developed economies, as one might expect. In contrast, codetermination is more prevalent in countries that emphasize selfexpression more (the correlation with Survival vs. Self-Expression is 0.323). Since Women Housewife, Child Independence and Women's Rights are just one of the many factors that enter into the construction of Traditional vs. Secular and Survival vs. Self-Expression, the positive coefficients on Fraction Family Firm and Codetermination are likely to be driven by omitted variable bias. Consistent with this argument, we also observe that the coefficients on Female Fulltime Economic Participation are larger than in most previous specifications (e.g. 0.621 in column 3 and 0.506 in column 4), which also suggests the coefficients may be biased in these specifications (upwards for Fulltime Economic Participation) due to omitted cultural factors.

Although the magnitudes of the coefficients on Fulltime Economic Participation are similar in the full specifications including Traditional vs. Secular and Survival vs. Self-Expression (ranging from 0.369 to 0.474 ), it is still possible that these coefficients are biased due to other omitted variables. To address this issue, we perform an instrumental variable analysis in which we instrument Fulltime Economic Participation with two instruments. The first is an index of alternative employment contracts from Botero et al. (2004). This index measures whether the cost of employing part-time workers is similar to the cost of employing full-time workers. For example, two components of this index are dummy variables equal to one if part-time workers enjoy the mandatory benefits of full-time workers or terminating part-time workers is at least as costly as terminating full time workers. We expect this index to be positively related to Fulltime Economic Participation because full-time employment should be higher when it is costly to employ part-time workers. On the other hand, the costs of part-time contracts should not matter for career advancement once women work full-time. Thus, we believe it is plausibly exogenous in our Director Participation regressions. Our second instrument is latitude from the dataset in La Porta et. al (2004). The reason we choose latitude is because Alesina, Giuliano and Nunn (2012) argue that the use of the plough is related to female labor force participation. An examination of the distribution of plough use around the world in Figures 3 and 4 of their paper suggests that latitude is a rough proxy for plough use, as there is very little plough use close to the equator. Again, once women work full-time, it is not clear why latitude should be related to their career advancement controlling for cultural factors and economic development. Thus, we believe it is plausibly exogenous in our Director Participation regressions.

We estimate specification 5 of Table VIII using instrumental variable regressions. Because the number of variables (including year dummies) is greater in our specifications than the number of 
clusters, we partial out the coefficients on our baseline controls and the birthrate. ${ }^{15}$ In column 1 of Table XII we report the first stage regression.

It is clear that both instruments are positively and significantly related to Fulltime Economic Participation, as one should expect. The Kleibergen-Paap Wald Statistic is 29.13 which is well above the Stock-Yogo 10\% weak identification test critical value (assuming i.i.d. standard errors) of 19.93. This suggests that the instruments are not too weak for valid inference. Under the assumption of instrument validity we reject the hypothesis that Fulltime Economic Participation is uncorrelated with the error term, albeit at a low level of significance (the Durbin-Wu-Hausman test statistic for endogeneity is 2.772 with a P-value of 0.0959 ). This suggests that our previous results may suffer from some omitted variable bias.

In column 2 of Table XII, we report the second stage regressions. We report the coefficient times the standard deviation in column 3. The coefficient on Fulltime Economic Participation is statistically significant at the 1\% level and about 50\% larger than in Table VIII. Column 3 suggests that a one standard deviation increase in Female Fulltime Economic Participation leads to a $3.4 \%$ increase in Director Participation. This is larger than the coefficients on the Corporate Governance Code dummy.

Our results suggest that working full-time is an important pre-condition for women to reach the boardroom. However, it may not be sufficient. The level of family services in a country and cultural attitudes also appear to matter for career advancement. Policies also have a direct effect. This suggests that there is little evidence female preferences are important for explaining their relative underrepresentation. When policies are implemented that encourage firms to appoint female directors, firms seem to be able to find women to fill the board positions. Finally, our results highlight that policies that target boards directly may not be sufficient to increase Director Participation. Other factors related to the labor market for women are also important.

\section{Country-level Characteristics and Director Participation- The Case of EDs}

We replicate Table VIII, IX and XII for executive directors. Table XIII highlights that full-time female employment is important for Executive Director Participation. However the economic magnitudes of the coefficients are much smaller than for NEDs. A one standard deviation increase in Fulltime Economic Participation in column 5 is associated with only a $0.7 \%$ increase in Executive Director Participation.

\footnotetext{
${ }^{15}$ In IV two-step GMM and LIML estimation the coefficients for the remaining regressors are the same as those that would be obtained if the variables were not partialled out according to the Frisch-Waugh-Lovell (FWL) theorem.
} 
Table XIV shows that very few of the other variables we consider has much explanatory power for Executive Director Participation. There is some evidence that taxes may matter, as it did for NEDs. Also, the presence of quotas for state-owned companies seems important. Again, this suggests that the role of female preferences may not be that important in explaining Director Participation. It also suggests that policies that target NEDs (quotas and governance codes) may not open the doors of the executive suite to more women-at least in the short run.

When we instrument Fulltime Economic Participation as before, the magnitude of the coefficient on Fulltime Economic Participation increases to $10.6 \%$. The P-value for the endogeneity test is 0.0186. Although there may simply be too many women in executive positions to conduct a meaningful analysis of factors that influenced their careers, it still appears as if Fulltime Economic Participation is an important factor.

\section{Conclusion}

To reach a board position, women need to stay in the work-force. But our evidence suggests that full-time employment may not be sufficient. The level of government services to families also appears important. More services make it easier for women to remain in the workforce. Our evidence also suggests that cultural barriers may be impediments to career progression. These may be more difficult to overcome than other barriers. It is possible that policies that target boards directly may help overcome cultural barriers in the long-run. On the other hand, they could also reinforce gender stereotypes. We suggest that a better understanding of the impediments for female representation in boardrooms is important to be able to assess the implications of boardroom gender policies. It may be more important to address the underlying causes of relative female underrepresentation than to target boardrooms directly. Moreover, it is not clear that boardroom diversity leads to more women in executive positions. 


\section{References}

Adams, Renée B. and Daniel Ferreira (2009) "Women in the boardroom and their impact on governance and performance," J. Financial Econom, 94(2), 291-309.

Adams, Renée, John Nowland and Steve Grey (2011) "Does Gender Matter in the Boardroom? Evidence from the Market Reaction to Mandatory New Director Announcements," Available at SSRN: http://ssrn.com/abstract=1953152.

Adams, Renée B., Amir Licht and Lilach Sagiv (2011) "Shareholders and Stakeholders: How Do Directors Decide?” Strategic Management Journal, 32 (12), 1331-1355.

Adams, Renée B. and Patricia C. Funk (2012) "Beyond the Glass Ceiling: Does Gender Matter?" Management Science 58(2), 219-235.

Ahern, Kenneth and Amy Dittmar (2012) "The Changing of the Boards: The Impact on Firm Valuation of Mandated Female Board Representation," forthcoming The Quarterly Journal of Economics, doi: 10.1093/qje/qjr049.

Alberto Alesina and Paola Giuliano (2010) "The Power of the Family" Journal of Economic Growth, 15 (2), 93-125.

Alesina, Alberto, Yann Algan, Pierre Cahuc, and Paola Giuliano (2011) "Family Values and the Regulation of Labor," Fondazione Eni Enrico Mattei Working Paper 445.

Alesina, Alberto, Paola Giuliano and Nathan Nunn (2012) "On the Origins of Gender Roles: Women and the Plough,” Working paper, Harvard University.

Bertrand, Marianne, \& Hallock, Kevin. (2001) "The gender gap in top corporate jobs," Industrial and Labor Relations Review 55, 3-21. [Electronic version]

Bertrand, Marianne (2010) "New Perspectives on Gender" Handbook of Labor Economics, Volume 4b, Elsevier Ltd. ISSN 0169-7218, DOI 10.1016/S0169-7218(11)02415-4. 1545-1592.

Bertrand, Marianne (2010), "CEOS”, Annu. Rev. Econ. 1, 121-49.

Black, Sandra E. and Chinhui Juhn (2000) “The Rise of Female Professionals: Are Women Responding to Skill Demand?” American Economic Review, 90(2), 450-455.

Blau, Francine D. and Lawrence M. Kahn (2003) "Understanding International Differences in the Gender Pay Gap" Journal of Labor Economics, 21(1), 106-144.

Bøhren, Øyvind and Siv Staubo (2012) "Changing organizational form to avoid regulatory constraints: The effect of mandatory gender balance in the boardroom" Working paper, Norwegian School of Business.

Botero, Juan, Simeon Djankov, Rafael La Porta, Florencio Lopez de Silanes and Andrei Shleifer (2004), “The Regulation of Labor," Quarterly Journal of Economics, 119(4), 1339-1382.

Catalyst (2012) "Women on Boards," Available electronically.

Davies, Lord (2011) 'Women on Boards'. Available electronically. 
Doldor, Elena, Susan Vinnicombe, Mary Gaughan and Ruth Sealy (2012) "Gender Diversity on Boards: The Appointment Process and the Role of Executive Search Firms," Equality and Human Rights Commission Research report 85, Available electronically.

Eckstein, Zvi and Osnat Lifshitz, (2011a) "Dynamic Female Labor Supply", Econometrica, Vol. 79, No. 6, 1675-1726.

Eckstein, Zvi and Osnat Lifshitz, (2011b) "Household Interaction and the Labor Supply of Married Women", Working paper, Tel Aviv University.

European Commission (2012a) "Proposal for a directive of the European Parliament and of the Council on improving the gender balance among non-executive directors of companies listed on stock exchanges and related measures". Available electronically.

European Commission (2012b) "Progress on equality between women and men in 2011," Commission Staff Working Document, available electronically.

European Union (201b) "Women in economic decision-making in the EU: Progress report," Luxembourg: Publications office of the European Union doi: 10.2838/65541, available electronically.

Faccio, Mara and Larry H. P. Lang (2002) "The ultimate ownership of western European corporations," Journal of Financial Economics, 65(3), 365-395.

Fernandez, Raquel (2007) "Women, Work, and Culture," Journal of the European Economic Association, 5(2-3), 305-332.

Fernandez, Raquel and Alessandra Fogli (2009) "Culture: An Empirical Investigation of Beliefs, Work, and Fertility,” American Economic Journal: Macroeconomics, 1:1, 146-177.

Goldin, Claudia (1991): "The Role of World War II in the Rise of Women's Employment," American Economic Review, 81, 741-756.

GovernanceMetrics International (2010) "Women on Boards," Available electronically.

Hausmann, Ricardo, Laura D. Tyson, Saadia Zahidi (2010) “The Global Gender Gap Report” World Economic Forum, Geneva Switzerland, available electronically.

Inglehart, Ronald and Christian Welzel, (2005) Modernization, Cultural

Change and Democracy, New York: Cambridge University Press.

International Labor Organization (1997) "Part-time work: Solution or Trap?" International Labor Review, 136(4), available electronically.

Kluge, N., \& Stollt, M. (Eds.) 2006. Die Europäische Aktiengesellschaft (SE) Perspektiven für eine europäische Unternehmensmitbestimmung. Brussels: ETUI-REHS, Available electronically.

La Porta, Rapael, Florencio Lopez-de-Silanes, Cristian Pop-Eleches, Andrei Shleifer (2004) “Judicial Checks and Balances," Journal of Political Economy, vol. 112, no. 2, 445-470. 
Matsa, David A. and Miller, Amalia R. (2011) “A Female Style in Corporate Leadership? Evidence from Quotas," forthcoming American Economic Journal: Applied Economics, Available at SSRN: http://ssrn.com/abstract $=1636047$.

Matsa, David A and Amalia Miller (2012) "Workforce Reductions at Women-Owned Businesses in the United States", Working paper, Available at SSRN: http://ssrn.com/abstract $=1973762$

Norris, Pippa and Ronald Inglehart, (2008) "Cracking the Marble Ceiling: Cultural barriers facing women leaders," Harvard University Report. Available electronically.

Osterloh, Margit, Bruno S. Frey and Hossam Zeitoun (2011) "Voluntary Co-determination produces sustainable competitive advantage," Corporate Social Responsibility and Corporate Governance: The Contribution of Economic Theory and Related Disciplines (International Economic Association), Editors: Lorenzo Sacconi, Margaret Blair, R. Edward Freeman, Alessandro Vercelli, Palgrave MacMillan, New York, NY.

Pande, Rohini and Dianna Ford (2011) "Gender Quotas and Female Leadership: A Review" Background paper for World Development Report 2012 on Gender Equality and Development. Available electronically.

Paul Hastings (2012) "Breaking the Glass Ceiling: Women in the Boardroom Second Edition", Tara Giunta, Lianne Labossiere, Paul Hastings (Editors), Paul Hastings, LLP, Available electronically.

Psacharopoulos, George and Zafiris Tzannatos "Female Labor Force Participation: An International Perspective" (1989) World Bank Research Observer 4(2), 187-201.

Sanders, Melanie, Jayne Hrdlicka, Meredith Hellicar, Dale Cottrell, and Joanna Knox (2011) "What stops women from reaching the top? Confronting the tough issues," Bain \& Company, Inc.

Soares, Rachel, Jan Combopiano, Allyson Regis, Yelena Shur, and Rosita Wong (2010) 2010 Catalyst Census: Fortune 500 Women Board Directors, Catalyst, Available electronically. 
Table I: Policy Initiatives as of 2012

This Table shows countries with different policies in place as of December 2012 regarding boardroom gender diversity, as well as countries with co-determination laws that involve board-level employee representation. We use European Union (2012) and Paul Hastings (2012) to identify countries with policies targeting gender diversity on boards. We then verify the data using the original source documents. We use the ECGI code database to identify whether a country's governance code mentions that gender must be considered by the board in nominations. If so, then Code $=1$. If the main stock exchange or securities laws stipulate that board diversity should be disclosed, we code Disclosure rule as 1 . We obtain information on co-determination laws from Kluge and Stollt (2006) and Osterloh, Frey and Zeitoun (2011).

\begin{tabular}{|c|c|c|c|c|c|c|}
\hline Country & Companies Affected & $\begin{array}{l}\text { Co- } \\
\text { determi- } \\
\text { nation }\end{array}$ & Code & Quota & $\begin{array}{l}\text { Quota: } \\
\text { State- } \\
\text { owned }\end{array}$ & $\begin{array}{l}\text { Disclo- } \\
\text { sure } \\
\text { Rule }\end{array}$ \\
\hline Australia & All Australian Listed Companies on the ASX & 0 & 0 & 0 & 0 & 1 \\
\hline Austria & Joint-stock companies/Limited Liability companies $>300$ employees & 1 & 0 & 0 & 0 & 0 \\
\hline Austria & State-owned companies & 0 & 0 & 0 & 1 & 0 \\
\hline Belgium & Autonomous public companies, listed companies and the National Lottery & 0 & 0 & 1 & 0 & 0 \\
\hline Denmark & Listed Companies & 0 & 1 & 0 & 0 & 0 \\
\hline Denmark & State-owned companies & 0 & 0 & 0 & 1 & 0 \\
\hline Denmark & $>35$ employees & 1 & 0 & 0 & 0 & 0 \\
\hline France & All French Companies trading on a regulated market & 0 & 1 & 0 & 0 & 0 \\
\hline France & $\begin{array}{l}\text { Public Limited Companies (Listed companies and non-listed companies } \\
\text { with assets }>50 \mathrm{~m} \text { or employees }>500 \text { ) }\end{array}$ & 0 & 0 & 1 & 0 & 0 \\
\hline Germany & Affects all German Listed Companies & 0 & 1 & 0 & 0 & 0 \\
\hline Germany & $500-2000$ employees/>2000 employees & 1 & 0 & 0 & 0 & 0 \\
\hline Greece & State-owned companies & 1 & 0 & 0 & 0 & 0 \\
\hline Greece & State-owned companies & 0 & 0 & 0 & 1 & 0 \\
\hline Ireland & State-owned Enterprises & 0 & 0 & 0 & 1 & 0 \\
\hline Ireland & State-owned companies (20), several privatised companies & 1 & 0 & 0 & 0 & 0 \\
\hline Netherlands & $\begin{array}{l}>100 \text { employees or equity capital }>16 \text { Million Euro or existence of a works } \\
\text { council }\end{array}$ & 1 & 0 & 0 & 0 & 0 \\
\hline Norway & Public Limited, State owned, Inter-municipal Companies & 0 & 0 & 1 & 0 & 0 \\
\hline Norway & Listed Companies & 0 & 1 & 0 & 0 & 0 \\
\hline Portugal & State-owned companies & 1 & 0 & 0 & 0 & 0 \\
\hline Spain & All Spanish Listed Companies & 0 & 1 & 0 & 0 & 0 \\
\hline Spain & Public Limited Companies with 250 or more employees & 0 & 0 & 1 & 0 & 0 \\
\hline Spain & 26 state-owned companies, 46 credit unions & 1 & 0 & 0 & 0 & 0 \\
\hline Sweden & All Swedish Listed Companies & 0 & 1 & 0 & 0 & 0 \\
\hline Sweden & 25-1000 employees/>1000 employees & 1 & 0 & 0 & 0 & 0 \\
\hline $\begin{array}{l}\text { United } \\
\text { Kingdom }\end{array}$ & Applies to all companies with primary listing in the UK & 0 & 1 & 0 & 0 & 0 \\
\hline USA & Listed Companies & 0 & 0 & 0 & 0 & 1 \\
\hline
\end{tabular}




\section{Table II: BoardEx and FactSet Ownership Coverage}

This table shows the firm coverage of BoardEx per country-year as a fraction of the aggregated market value of all listed firms. We determine the latter by aggregating the population of listed firms in CapitalIQ, which itself claims to have a $99 \%$ coverage of all listed firms worldwide. Only country-year observations are recorded that combine at least 10 firms in both BoardEx and CapitalIQ. We define the BoardEx sample to be representative if BoardEx covers at least $70 \%$ of its market cap for that year. Using the information about the representativeness of BoardEx, we collect data on closely-held shares (FF_SHS_CLOSELY_HELD) from FactSet. Closely-held shares include shares held by officers, directors and their families, shares held in trust and shares held by pension plans and 5\% blockholders. The average coverage of ownership data in Factset for the representative BoardEx sample years is depicted in the last column.

\begin{tabular}{|c|c|c|c|c|c|c|c|c|c|c|c|}
\hline country & 2001 & 2002 & 2003 & 2004 & 2005 & 2006 & 2007 & 2008 & 2009 & 2010 & $\begin{array}{c}\text { Average } \\
\text { Factset } \\
\text { Coverage }\end{array}$ \\
\hline Australia & & & 0.387 & 0.733 & 0.830 & 0.802 & 0.849 & 0.889 & 0.896 & 0.918 & 0.921 \\
\hline Austria & & & & & & & 0.885 & 0.956 & 0.961 & 0.944 & 0.886 \\
\hline Belgium & 0.855 & 0.663 & 0.704 & 0.664 & 0.710 & 0.684 & 0.707 & 0.886 & 0.891 & 0.878 & 0.883 \\
\hline Bermuda & 0.308 & 0.436 & 0.497 & 0.508 & 0.705 & 0.746 & 0.864 & 0.783 & 0.830 & 0.657 & 0.852 \\
\hline Brazil & & & & & & & & 0.434 & & & \\
\hline Canada & & & 0.582 & 0.631 & 0.697 & 0.759 & 0.864 & 0.878 & 0.869 & 0.856 & 0.666 \\
\hline China & & & & 0.003 & 0.059 & 0.058 & 0.342 & 0.383 & 0.297 & 0.238 & \\
\hline Denmark & 0.698 & 0.645 & 0.777 & 0.769 & 0.847 & 0.826 & 0.872 & 0.900 & 0.912 & 0.921 & 0.941 \\
\hline Finland & & & 0.800 & 0.761 & 0.822 & 0.847 & 0.894 & 0.891 & 0.849 & 0.836 & 0.974 \\
\hline France & 0.928 & 0.922 & 0.872 & 0.912 & 0.934 & 0.939 & 0.938 & 0.975 & 0.951 & 0.945 & 0.952 \\
\hline Germany & 0.895 & 0.851 & 0.870 & 0.878 & 0.880 & 0.879 & 0.899 & 0.874 & 0.875 & 0.887 & 0.864 \\
\hline Greece & & 0.603 & 0.656 & 0.787 & 0.778 & 0.739 & 0.734 & 0.775 & 0.805 & 0.775 & 0.636 \\
\hline Hong Kong & & & & & 0.155 & 0.193 & 0.357 & 0.529 & 0.357 & 0.316 & \\
\hline India & & & & & & 0.166 & 0.384 & 0.786 & 0.788 & 0.753 & 0.897 \\
\hline Ireland & 0.927 & 0.883 & 0.959 & 0.968 & 0.979 & 0.937 & 0.989 & 0.993 & 0.939 & 0.999 & 0.932 \\
\hline Israel & & 0.041 & 0.180 & 0.245 & 0.198 & 0.188 & 0.215 & 0.277 & 0.234 & 0.201 & \\
\hline Italy & 0.735 & 0.671 & 0.793 & 0.786 & 0.813 & 0.823 & 0.871 & 0.882 & 0.900 & 0.895 & 0.917 \\
\hline Japan & & & & & & & 0.050 & 0.196 & 0.204 & 0.200 & \\
\hline Luxembourg & & & & & & & 0.537 & 0.687 & 0.804 & 0.780 & 0.706 \\
\hline Malaysia & & & & & & & 0.039 & 0.060 & 0.060 & 0.062 & \\
\hline
\end{tabular}




\begin{tabular}{|c|c|c|c|c|c|c|c|c|c|c|c|}
\hline country & 2001 & 2002 & 2003 & 2004 & 2005 & 2006 & 2007 & 2008 & 2009 & 2010 & $\begin{array}{c}\text { Average } \\
\text { Factset } \\
\text { Coverage }\end{array}$ \\
\hline Netherlands & 0.742 & 0.717 & 0.769 & 0.755 & 0.853 & 0.845 & 0.809 & 0.951 & 0.917 & 0.941 & 0.813 \\
\hline Norway & 0.904 & 0.836 & 0.940 & 0.932 & 0.911 & 0.846 & 0.858 & 0.874 & 0.864 & 0.849 & 0.777 \\
\hline Poland & & & & & & & 0.643 & 0.687 & 0.580 & 0.518 & \\
\hline Portugal & & & 0.760 & 0.804 & 0.831 & 0.770 & 0.972 & 0.979 & 0.974 & 0.978 & 0.929 \\
\hline Russia & & & & & & & & & & 0.638 & \\
\hline Singapore & & & & & & & 0.210 & 0.424 & 0.377 & 0.343 & \\
\hline South Africa & & & & & & 0.085 & 0.289 & 0.476 & 0.497 & 0.512 & \\
\hline Spain & 0.858 & 0.868 & 0.890 & 0.886 & 0.897 & 0.888 & 0.890 & 0.928 & 0.935 & 0.912 & 0.946 \\
\hline Sweden & 0.859 & 0.921 & 0.927 & 0.933 & 0.924 & 0.890 & 0.903 & 0.924 & 0.921 & 0.913 & 0.868 \\
\hline Switzerland & 0.942 & 0.914 & 0.909 & 0.915 & 0.924 & 0.923 & 0.907 & 0.930 & 0.932 & 0.892 & 0.906 \\
\hline Turkey & & & & & & & 0.522 & 0.272 & 0.487 & 0.410 & \\
\hline United Kingdom & 0.863 & 0.876 & 0.906 & 0.943 & 0.969 & 0.964 & 0.967 & 0.979 & 0.972 & 0.986 & 0.923 \\
\hline United States & 0.060 & 0.052 & 0.532 & 0.811 & 0.879 & 0.881 & 0.841 & 0.882 & 0.942 & 0.947 & 0.902 \\
\hline
\end{tabular}




\section{Table III: Summary Statistics - Panel A}

This table provides country averages of our main variables. Column (1), (2) and (3) shows the female director participation levels, which we calculate as the number of unique female directors in a given year and country over all unique directors. Column (1) shows the country averages for the entire board, (2) and (3) for the subgroups of executive, and non-executive directors respectively. Column (4) exhibits boardroom diversity measured as the average of the number of women over board size, (5) the average number of individual-level current board seats, with the minimum being 1. Column (6), (7), (8) and (9) summarizes different measures of female participation ratios. (6) measures the ratio of women in full-time employment over all full time employed, (7) the ratio of women in full-time employment over the labor force, and (8) female labor force over the entire labor force. All three measures are conceptually similar to (1). The classical measure Female Labor Force Participation, hence female labor force (employed + unemployed) over female population, is in (9). The fractions of family firms in our sample period is in (10). We define family firms as having at least two directors with the same last name on the board with a fraction of closely held shares of at least $20 \%$. The fraction of women in higher education is in (11). The birth rate in (13) shows the number of births per 1000 inhabitants. The gross national income per capita in US\$ in constant 2011 prices and exchange rates is in (13). The fraction of tax and social security receipts over gross income is listed in (14). The average wage equality figures as collected by the World Economic Forum for 2006-10 are in (15). A society's values as defined by Inglehart and Welzel (2005) as traditional vs. secular (sec.) and survival vs. self-expression (self.) respectively are listed in (16) and (17). Data on directors is from Boardex. Data on closely-held shares is from Factset. Data on variables in columns (6)-(15) is from Euromonitor. Variables in (6)-(9), (11)-(14) are lagged by 10 years.

\begin{tabular}{|c|c|c|c|c|c|c|c|c|c|c|c|c|c|c|c|c|c|}
\hline & \multicolumn{3}{|c|}{$\begin{array}{l}\text { Female Director } \\
\text { Participation }\end{array}$} & \multirow[t]{2}{*}{ Div. } & \multirow[t]{2}{*}{ Busy } & \multicolumn{4}{|c|}{$\begin{array}{c}\text { Female Labor Force } \\
\text { Participation }\end{array}$} & \multirow[t]{2}{*}{$\begin{array}{l}\text { Family } \\
\text { Firms }\end{array}$} & \multirow[t]{2}{*}{$\begin{array}{l}\text { High. } \\
\text { Edu }\end{array}$} & \multirow[t]{2}{*}{$\begin{array}{l}\text { Birth } \\
\text { Rate }\end{array}$} & \multirow[t]{2}{*}{ Inc. pp } & \multirow[t]{2}{*}{$\begin{array}{c}\text { Tax } \\
/ \\
\text { Inc. }\end{array}$} & \multirow[t]{2}{*}{$\begin{array}{l}\text { Wage } \\
\text { Equal. }\end{array}$} & \multicolumn{2}{|c|}{ Values } \\
\hline & ALL & ED & NED & & & & & & & & & & & & & Sec. & Self. \\
\hline & $(1)$ & (2) & $(3)$ & (4) & $(5)$ & (6) & (7) & (8) & (9) & (10) & (11) & (12) & (13) & (14) & (15) & (16) & (17) \\
\hline Australia & 0.069 & 0.028 & 0.083 & 0.063 & 1.407 & 0.351 & 0.246 & 0.431 & 0.427 & 0.058 & 0.575 & 13.7 & 46,107 & 22.7 & 4.67 & 0.21 & 1.75 \\
\hline Austria & 0.062 & 0.028 & 0.074 & 0.053 & 1.323 & 0.374 & 0.318 & 0.432 & 0.407 & 0.125 & 0.497 & 10.1 & 43,010 & 34.0 & 3.39 & 0.25 & 1.43 \\
\hline Belgium & 0.079 & 0.059 & 0.083 & 0.074 & 1.353 & 0.332 & 0.256 & 0.418 & 0.340 & 0.330 & 0.510 & 11.6 & 40,577 & 35.8 & 4.38 & 0.50 & 1.13 \\
\hline Bermuda & 0.048 & 0.022 & 0.055 & 0.062 & 1.253 & & & & & 0.128 & 0.579 & 13.4 & & & & & \\
\hline Canada & 0.084 & 0.038 & 0.096 & 0.075 & 1.294 & 0.403 & 0.300 & 0.456 & 0.459 & 0.082 & 0.550 & 11.3 & 39,710 & 21.7 & 5.11 & -0.26 & 1.91 \\
\hline Denmark & 0.123 & 0.074 & 0.135 & 0.113 & 1.287 & 0.412 & 0.320 & 0.463 & 0.492 & 0.320 & 0.542 & 12.9 & 52,153 & 34.8 & 4.85 & 1.16 & 1.87 \\
\hline Finland & 0.206 & 0.097 & 0.209 & 0.207 & 1.273 & 0.455 & 0.360 & 0.471 & 0.456 & 0.028 & 0.533 & 11.8 & 35,717 & 36.7 & 4.85 & 0.82 & 1.12 \\
\hline France & 0.089 & 0.064 & 0.094 & 0.090 & 1.489 & 0.390 & 0.302 & 0.451 & 0.395 & 0.353 & 0.545 & 12.7 & 37,853 & 33.0 & 3.26 & 0.63 & 1.13 \\
\hline Germany & 0.076 & 0.018 & 0.097 & 0.061 & 1.309 & 0.351 & 0.275 & 0.431 & 0.404 & 0.159 & 0.451 & 9.7 & 39,760 & 14.0 & 4.23 & 1.31 & 0.74 \\
\hline Greece & 0.066 & 0.066 & 0.067 & 0.065 & 1.214 & 0.343 & 0.282 & 0.391 & 0.315 & 0.264 & 0.492 & 9.5 & 22,067 & 18.9 & 4.36 & 0.77 & 0.55 \\
\hline India & 0.049 & 0.030 & 0.058 & 0.049 & 1.716 & 0.247 & 0.229 & 0.252 & 0.186 & 0.440 & 0.371 & 27.6 & 867 & 2.3 & 4.57 & -0.36 & -0.21 \\
\hline Ireland & 0.054 & 0.033 & 0.065 & 0.053 & 1.202 & 0.309 & 0.234 & 0.371 & 0.305 & 0.126 & 0.507 & 14.2 & 30,103 & 27.7 & 4.96 & -0.91 & 1.18 \\
\hline Italy & 0.040 & 0.035 & 0.041 & 0.044 & 1.406 & 0.315 & 0.250 & 0.376 & 0.299 & 0.371 & 0.536 & 9.4 & 33,164 & 29.2 & 3.68 & 0.13 & 0.60 \\
\hline Luxembourg & 0.040 & 0.000 & 0.047 & 0.043 & 1.111 & 0.317 & 0.265 & 0.398 & 0.331 & 0.148 & 0.519 & 12.6 & 78,045 & & 4.83 & 0.42 & 1.13 \\
\hline Netherlands & 0.058 & 0.025 & 0.077 & 0.054 & 1.362 & 0.266 & 0.179 & 0.415 & 0.398 & 0.033 & 0.475 & 12.7 & 39,940 & 43.0 & 4.44 & 0.71 & 1.39 \\
\hline
\end{tabular}




\begin{tabular}{|c|c|c|c|c|c|c|c|c|c|c|c|c|c|c|c|c|c|}
\hline Norway & 0.244 & 0.057 & 0.254 & 0.251 & 1.124 & 0.369 & 0.277 & 0.459 & 0.463 & 0.115 & 0.554 & 13.7 & 55,929 & 33.7 & 5.05 & 1.39 & 2.17 \\
\hline Portugal & 0.031 & 0.040 & 0.024 & 0.037 & 1.171 & 0.415 & 0.355 & 0.448 & 0.427 & 0.530 & 0.562 & 11.2 & 18,886 & 23.2 & 4.32 & -0.90 & 0.49 \\
\hline Spain & 0.058 & 0.023 & 0.066 & 0.065 & 1.361 & 0.314 & 0.235 & 0.379 & 0.308 & 0.447 & 0.524 & 9.6 & 24,364 & 29.3 & 3.40 & 0.09 & 0.54 \\
\hline Sweden & 0.192 & 0.031 & 0.207 & 0.183 & 1.499 & 0.429 & 0.343 & 0.474 & 0.478 & 0.159 & 0.555 & 11.8 & 39,088 & 42.0 & 4.97 & 1.86 & 2.35 \\
\hline Switzerland & 0.060 & 0.021 & 0.072 & 0.057 & 1.226 & 0.317 & 0.234 & 0.441 & 0.476 & 0.076 & 0.388 & 11.7 & 72,437 & 19.6 & 4.51 & 0.74 & 1.90 \\
\hline United Kingdom & 0.055 & 0.044 & 0.063 & 0.054 & 1.508 & 0.342 & 0.245 & 0.441 & 0.423 & 0.073 & 0.516 & 12.7 & 29,120 & 29.9 & 4.52 & 0.06 & 1.68 \\
\hline United States & 0.085 & 0.040 & 0.095 & 0.080 & 1.809 & 0.432 & 0.361 & 0.463 & 0.452 & 0.099 & 0.558 & 14.4 & 43,337 & 22.2 & 4.69 & -0.81 & 1.76 \\
\hline
\end{tabular}




\section{Table III: Summary Statistics - Panel B}

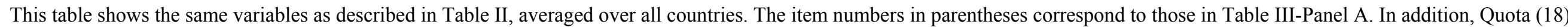

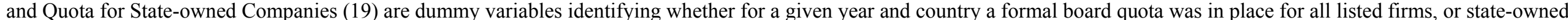

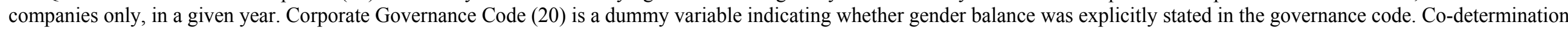

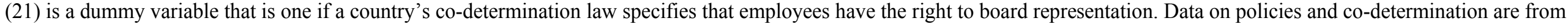
Table I. For a detailed description of all other variables see Table III Panel A. Norway is excluded.

\begin{tabular}{|c|c|c|c|c|c|c|c|}
\hline & & & Obs. & Mean & Std. Dev. & Min & Max \\
\hline \multirow{3}{*}{$\begin{array}{l}\text { Female Director } \\
\text { Participation }\end{array}$} & Board & (1) & 160 & 0.080 & 0.050 & 0.009 & 0.258 \\
\hline & ED & (2) & 160 & 0.040 & 0.033 & 0.000 & 0.250 \\
\hline & NED & (3) & 160 & 0.090 & 0.052 & 0.010 & 0.255 \\
\hline Diversity & & (4) & 160 & 0.078 & 0.045 & 0.037 & 0.207 \\
\hline \multirow[t]{2}{*}{ Busyness } & & (5) & 160 & 1.352 & 0.150 & 1.037 & 1.803 \\
\hline & & (6) & 155 & 0.357 & 0.055 & 0.233 & 0.466 \\
\hline Female Labor Force & & $(7)$ & 155 & 0.277 & 0.053 & 0.171 & 0.372 \\
\hline \multirow[t]{2}{*}{ Participation } & & (8) & 155 & 0.425 & 0.042 & 0.240 & 0.476 \\
\hline & & (9) & 155 & 0.396 & 0.072 & 0.174 & 0.509 \\
\hline Family Firms & & $(10)$ & 160 & 0.207 & 0.155 & 0.000 & 0.600 \\
\hline Female in Higher Edu. & & (11) & 156 & 0.510 & 0.055 & 0.347 & 0.600 \\
\hline Birth Rate & & (12) & 160 & 12.110 & 2.704 & 9.100 & 28.200 \\
\hline Income pp & & (13) & 155 & 37,891 & 14,291 & 838 & 79,068 \\
\hline Tax / Income & & (14) & 153 & 28.462 & 8.954 & 1.900 & 45.700 \\
\hline Wage Equality & & (15) & 155 & 4.368 & 0.547 & 3.260 & 5.124 \\
\hline \multirow{2}{*}{ Values } & Sec. & (16) & 155 & 0.380 & 0.752 & -0.910 & 1.860 \\
\hline & Self. & (17) & 155 & 1.262 & 0.590 & -0.210 & 2.350 \\
\hline \multirow{3}{*}{ Policies } & Quota & (18) & 160 & 0.025 & 0.157 & 0.000 & 1.000 \\
\hline & State-owned & (19) & 160 & 0.138 & 0.345 & 0.000 & 1.000 \\
\hline & Code & (20) & 160 & 0.181 & 0.386 & 0.000 & 1.000 \\
\hline Co-determination & & $(21)$ & 160 & 0.606 & 0.490 & 0.000 & 1.000 \\
\hline
\end{tabular}




\section{Table IV: Female Director Participation in the Boardroom}

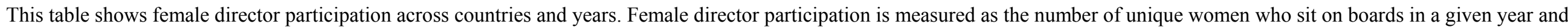

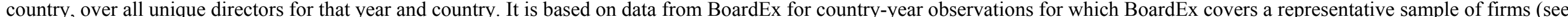
Table II). Investment firms are excluded.

\begin{tabular}{|c|c|c|c|c|c|c|c|c|c|c|}
\hline country & 2001 & 2002 & 2003 & 2004 & 2005 & 2006 & 2007 & 2008 & 2009 & 2010 \\
\hline Australia & & & & 0.083 & 0.070 & 0.071 & 0.061 & 0.065 & 0.065 & 0.074 \\
\hline Austria & & & & & & & 0.061 & 0.063 & 0.066 & 0.059 \\
\hline Belgium & 0.050 & & 0.061 & & 0.075 & & 0.082 & 0.081 & 0.096 & 0.110 \\
\hline Bermuda & & & & & 0.047 & 0.049 & 0.047 & 0.044 & 0.048 & \\
\hline Canada & & & & & & 0.089 & 0.080 & 0.075 & 0.083 & 0.091 \\
\hline Denmark & & & 0.113 & 0.124 & 0.114 & 0.113 & 0.117 & 0.134 & 0.137 & 0.131 \\
\hline Finland & & & 0.128 & 0.149 & 0.238 & 0.211 & 0.211 & 0.208 & 0.244 & 0.258 \\
\hline France & 0.073 & 0.071 & 0.083 & 0.078 & 0.080 & 0.084 & 0.092 & 0.096 & 0.103 & 0.131 \\
\hline Germany & 0.070 & 0.071 & 0.084 & 0.084 & 0.081 & 0.074 & 0.070 & 0.073 & 0.074 & 0.076 \\
\hline Greece & & & & 0.054 & 0.055 & 0.047 & 0.063 & 0.078 & 0.083 & 0.083 \\
\hline India & & & & & & & & 0.050 & 0.045 & 0.052 \\
\hline Ireland & 0.031 & 0.042 & 0.037 & 0.050 & 0.058 & 0.056 & 0.059 & 0.067 & 0.063 & 0.079 \\
\hline Italy & 0.028 & & 0.027 & 0.035 & 0.038 & 0.038 & 0.043 & 0.046 & 0.050 & 0.055 \\
\hline Luxembourg & & & & & & & & & 0.045 & 0.035 \\
\hline Netherlands & 0.048 & 0.047 & 0.044 & 0.045 & 0.052 & 0.054 & 0.064 & 0.066 & 0.074 & 0.083 \\
\hline Norway & 0.107 & 0.106 & 0.151 & 0.168 & 0.224 & 0.275 & 0.340 & 0.352 & 0.347 & 0.371 \\
\hline Portugal & & & 0.010 & 0.009 & 0.015 & 0.026 & 0.039 & 0.041 & 0.051 & 0.055 \\
\hline Spain & 0.025 & 0.033 & 0.031 & 0.031 & 0.042 & 0.059 & 0.069 & 0.088 & 0.100 & 0.107 \\
\hline Sweden & 0.108 & 0.123 & 0.160 & 0.195 & 0.200 & 0.214 & 0.228 & 0.234 & 0.226 & 0.233 \\
\hline Switzerland & 0.045 & 0.044 & 0.045 & 0.056 & 0.058 & 0.060 & 0.059 & 0.072 & 0.078 & 0.078 \\
\hline United Kingdom & 0.040 & 0.043 & 0.051 & 0.051 & 0.055 & 0.056 & 0.058 & 0.061 & 0.063 & 0.065 \\
\hline United States & & & & 0.079 & 0.081 & 0.082 & 0.082 & 0.085 & 0.089 & 0.093 \\
\hline
\end{tabular}




\section{Table V: Boardroom Diversity}

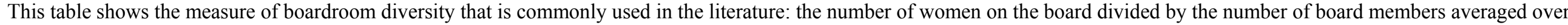

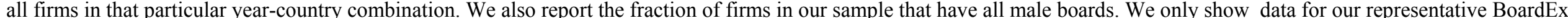
sample (see Table II). $\mathrm{N}$ denotes the number of firms in the sample. Investment firms are excluded.

\begin{tabular}{|c|c|c|c|c|c|c|c|c|c|c|c|}
\hline & & 2001 & 2002 & 2003 & 2004 & 2005 & 2006 & 2007 & 2008 & 2009 & 2010 \\
\hline \multirow[t]{3}{*}{ Australia } & Mean & & & & 0.089 & 0.065 & 0.066 & 0.057 & 0.060 & 0.059 & 0.068 \\
\hline & Male only & & & & 0.424 & 0.598 & 0.587 & 0.642 & 0.650 & 0.667 & 0.622 \\
\hline & $\mathrm{N}$ & & & & 92 & 165 & 192 & 278 & 336 & 324 & 323 \\
\hline \multirow[t]{3}{*}{ Austria } & Mean & & & & & & & 0.049 & 0.054 & 0.057 & 0.050 \\
\hline & Male only & & & & & & & 0.500 & 0.455 & 0.465 & 0.548 \\
\hline & $\mathrm{N}$ & & & & & & & 38 & 44 & 43 & 42 \\
\hline \multirow[t]{3}{*}{ Belgium } & Mean & 0.053 & & 0.057 & & 0.066 & & 0.074 & 0.073 & 0.086 & 0.100 \\
\hline & Male only & 0.703 & & 0.682 & & 0.646 & & 0.545 & 0.533 & 0.458 & 0.421 \\
\hline & $\mathrm{N}$ & 37 & & 44 & & 48 & & 55 & 60 & 59 & 57 \\
\hline \multirow[t]{3}{*}{ Bermuda } & Mean & & & & & 0.063 & 0.057 & 0.059 & 0.061 & 0.068 & \\
\hline & Male only & & & & & 0.632 & 0.604 & 0.603 & 0.632 & 0.618 & \\
\hline & $\mathrm{N}$ & & & & & 38 & 47 & 61 & 66 & 66 & \\
\hline \multirow[t]{3}{*}{ Canada } & Mean & & & & & & 0.079 & 0.066 & 0.067 & 0.077 & 0.088 \\
\hline & Male only & & & & & & 0.522 & 0.627 & 0.641 & 0.601 & 0.574 \\
\hline & $\mathrm{N}$ & & & & & & 182 & 318 & 350 & 348 & 329 \\
\hline \multirow[t]{3}{*}{ Denmark } & Mean & & & 0.102 & 0.114 & 0.110 & 0.100 & 0.104 & 0.118 & 0.124 & 0.125 \\
\hline & Male only & & & 0.176 & 0.235 & 0.136 & 0.250 & 0.222 & 0.148 & 0.111 & 0.148 \\
\hline & $\mathrm{N}$ & & & 17 & 17 & 22 & 24 & 27 & 27 & 27 & 27 \\
\hline \multirow[t]{3}{*}{ Finland } & Mean & & & 0.115 & 0.133 & 0.217 & 0.198 & 0.195 & 0.191 & 0.242 & 0.255 \\
\hline & Male only & & & 0.200 & 0.300 & 0.150 & 0.208 & 0.167 & 0.194 & 0.065 & 0.065 \\
\hline & $\mathrm{N}$ & & & 10 & 10 & 20 & 24 & 30 & 31 & 31 & 31 \\
\hline \multirow[t]{3}{*}{ France } & Mean & 0.069 & 0.065 & 0.085 & 0.081 & 0.083 & 0.086 & 0.088 & 0.093 & 0.100 & 0.123 \\
\hline & Male only & 0.495 & 0.532 & 0.487 & 0.506 & 0.483 & 0.463 & 0.419 & 0.379 & 0.366 & 0.258 \\
\hline & $\mathrm{N}$ & 111 & 124 & 150 & 164 & 205 & 216 & 235 & 247 & 245 & 232 \\
\hline
\end{tabular}




\begin{tabular}{|c|c|c|c|c|c|c|c|c|c|c|c|}
\hline & & 2001 & 2002 & 2003 & 2004 & 2005 & 2006 & 2007 & 2008 & 2009 & 2010 \\
\hline \multirow[t]{3}{*}{ Germany } & Mean & 0.061 & 0.062 & 0.072 & 0.071 & 0.065 & 0.057 & 0.055 & 0.058 & 0.059 & 0.060 \\
\hline & Male only & 0.354 & 0.371 & 0.313 & 0.333 & 0.435 & 0.500 & 0.506 & 0.497 & 0.470 & 0.475 \\
\hline & $\mathrm{N}$ & 96 & 97 & 99 & 105 & 147 & 160 & 176 & 177 & 168 & 160 \\
\hline \multirow[t]{3}{*}{ Greece } & Mean & & & & 0.049 & 0.045 & 0.037 & 0.065 & 0.075 & 0.078 & 0.078 \\
\hline & Male only & & & & 0.529 & 0.545 & 0.600 & 0.583 & 0.568 & 0.583 & 0.514 \\
\hline & $\mathrm{N}$ & & & & 17 & 22 & 25 & 36 & 37 & 36 & 37 \\
\hline \multirow[t]{3}{*}{ India } & Mean & & & & & & & & 0.049 & 0.046 & 0.051 \\
\hline & Male only & & & & & & & & 0.580 & 0.597 & 0.568 \\
\hline & $\mathrm{N}$ & & & & & & & & 138 & 139 & 139 \\
\hline \multirow[t]{3}{*}{ Ireland } & Mean & 0.032 & 0.039 & 0.034 & 0.045 & 0.054 & 0.054 & 0.057 & 0.061 & 0.058 & 0.072 \\
\hline & Male only & 0.706 & 0.711 & 0.729 & 0.620 & 0.600 & 0.597 & 0.603 & 0.573 & 0.594 & 0.507 \\
\hline & $\mathrm{N}$ & 34 & 38 & 48 & 50 & 60 & 67 & 73 & 75 & 69 & 69 \\
\hline \multirow[t]{3}{*}{ Italy } & Mean & 0.030 & & 0.029 & 0.037 & 0.040 & 0.041 & 0.045 & 0.048 & 0.052 & 0.057 \\
\hline & Male only & 0.707 & & 0.714 & 0.654 & 0.662 & 0.642 & 0.608 & 0.573 & 0.543 & 0.505 \\
\hline & $\mathrm{N}$ & 41 & & 49 & 52 & 74 & 81 & 97 & 96 & 92 & 93 \\
\hline \multirow[t]{3}{*}{ Luxembourg } & Mean & & & & & & & & & 0.049 & 0.038 \\
\hline & Male only & & & & & & & & & 0.692 & 0.786 \\
\hline & $\mathrm{N}$ & & & & & & & & & 13 & 14 \\
\hline \multirow[t]{3}{*}{ Netherlands } & Mean & 0.042 & 0.042 & 0.040 & 0.041 & 0.047 & 0.054 & 0.059 & 0.061 & 0.065 & 0.074 \\
\hline & Male only & 0.642 & 0.649 & 0.641 & 0.645 & 0.640 & 0.612 & 0.618 & 0.609 & 0.557 & 0.533 \\
\hline & $\mathrm{N}$ & 53 & 57 & 64 & 62 & 75 & 85 & 89 & 87 & 79 & 75 \\
\hline \multirow[t]{3}{*}{ Norway } & Mean & 0.086 & 0.080 & 0.124 & 0.149 & 0.213 & 0.274 & 0.355 & 0.369 & 0.362 & 0.379 \\
\hline & Male only & 0.595 & 0.583 & 0.426 & 0.333 & 0.217 & 0.097 & 0.046 & 0.016 & 0.017 & 0.018 \\
\hline & $\mathrm{N}$ & 37 & 48 & 54 & 60 & 60 & 62 & 65 & 63 & 58 & 57 \\
\hline \multirow[t]{3}{*}{ Portugal } & Mean & & & 0.014 & 0.014 & 0.018 & 0.027 & 0.037 & 0.039 & 0.050 & 0.051 \\
\hline & Male only & & & 0.900 & 0.900 & 0.818 & 0.667 & 0.760 & 0.704 & 0.615 & 0.560 \\
\hline & $\mathrm{N}$ & & & 10 & 10 & 11 & 12 & 25 & 27 & 26 & 25 \\
\hline \multirow[t]{3}{*}{ Spain } & Mean & 0.023 & 0.038 & 0.038 & 0.034 & 0.044 & 0.057 & 0.066 & 0.082 & 0.099 & 0.102 \\
\hline & Male only & 0.767 & 0.656 & 0.618 & 0.703 & 0.644 & 0.473 & 0.450 & 0.369 & 0.274 & 0.228 \\
\hline & $\mathrm{N}$ & 30 & 32 & 34 & 37 & 45 & 55 & 60 & 65 & 62 & 57 \\
\hline
\end{tabular}




\begin{tabular}{llcccccccccc}
\hline & & 2001 & 2002 & 2003 & 2004 & 2005 & 2006 & 2007 & 2008 & 2009 & 2010 \\
\hline Sweden & Mean & 0.091 & 0.104 & 0.142 & 0.179 & 0.184 & 0.206 & 0.215 & 0.223 & 0.222 & 0.233 \\
& Male only & 0.405 & 0.360 & 0.274 & 0.140 & 0.129 & 0.079 & 0.126 & 0.088 & 0.081 & 0.074 \\
& $\mathrm{~N}$ & 79 & 86 & 95 & 100 & 101 & 101 & 103 & 102 & 99 & 95 \\
Switzerland & Mean & 0.043 & 0.043 & 0.046 & 0.052 & 0.052 & 0.054 & 0.056 & 0.063 & 0.075 & 0.067 \\
& Male only & 0.571 & 0.608 & 0.593 & 0.591 & 0.613 & 0.605 & 0.596 & 0.543 & 0.495 & 0.511 \\
& $\mathrm{~N}$ & 49 & 51 & 54 & 66 & 80 & 86 & 94 & 94 & 91 & 92 \\
United & Mean & 0.037 & 0.039 & 0.046 & 0.045 & 0.050 & 0.053 & 0.056 & 0.057 & 0.060 & 0.064 \\
Kingdom & Male only & 0.743 & 0.734 & 0.713 & 0.732 & 0.713 & 0.713 & 0.706 & 0.696 & 0.696 & 0.677 \\
& $\mathrm{~N}$ & 448 & 515 & 630 & 772 & 996 & 1200 & 1324 & 1309 & 1256 & 1243 \\
United States & Mean & & & & 0.074 & 0.076 & 0.078 & 0.079 & 0.080 & 0.085 & 0.089 \\
& Male only & & & & 0.522 & 0.521 & 0.512 & 0.531 & 0.535 & 0.514 & 0.491 \\
& $\mathrm{~N}$ & & & & 3298 & 3655 & 3913 & 4506 & 4567 & 4314 & 4098 \\
\hline
\end{tabular}




\section{Table VI: Comparing Measures}

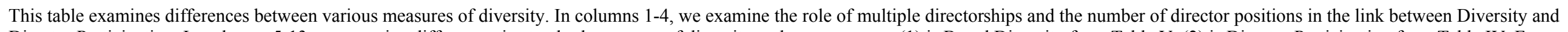

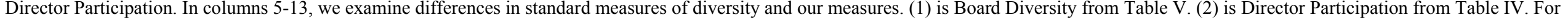

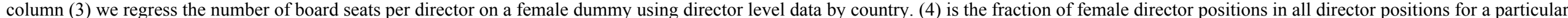

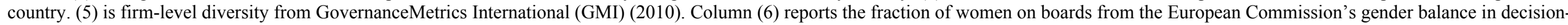

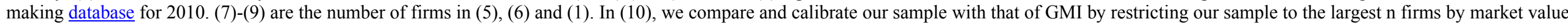

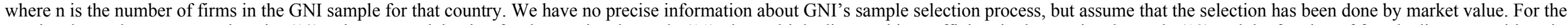

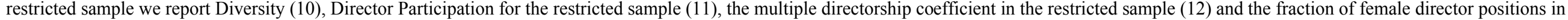
all director positions in the restricted sample for a particular country (13). All figures are for 2010, investment firms are excluded.

\begin{tabular}{|c|c|c|c|c|c|c|c|c|c|c|c|c|c|}
\hline & \multicolumn{4}{|c|}{ Moving from Diversity to Director Participation } & \multicolumn{9}{|c|}{$\begin{array}{c}\text { Comparing Standard Diversity Measures to our Measures } \\
\text { Dir }\end{array}$} \\
\hline & Diversity & Dir Part. & $\begin{array}{l}\text { Multiple } \\
\text { Dir. } \\
\text { Coeff. }\end{array}$ & $\begin{array}{c}\text { Fraction } \\
\text { Directors } \\
\text { hips } \\
\end{array}$ & $\begin{array}{c}\text { GMI- } \\
\text { Diversity }\end{array}$ & $\begin{array}{c}\text { EU- } \\
\text { Diversity }\end{array}$ & $\begin{array}{c}\text { GMI } \\
\# \text { firms }\end{array}$ & $\begin{array}{c}\text { EU } \\
\# \text { firms }\end{array}$ & $\begin{array}{l}\text { B'Ex } \\
\text { \#firms }\end{array}$ & $\begin{array}{l}\text { Diversity- } \\
\text { large } \\
\text { B'Ex } \\
\end{array}$ & $\begin{array}{c}\text { Participat } \\
\text { ion-large } \\
\text { B'Ex } \\
\end{array}$ & $\begin{array}{c}\text { Multiple Dir. } \\
\text { Coeff.-large } \\
\text { B'Ex }\end{array}$ & $\begin{array}{c}\text { Fraction } \\
\text { Directorships- } \\
\text { large B'Ex }\end{array}$ \\
\hline & $(1)$ & $(2)$ & $(3)$ & $(4)$ & $(5)$ & $(6)$ & $(7)$ & $(8)$ & $(9)$ & $(10)$ & $(11)$ & $(12)$ & $(13)$ \\
\hline Australia & 0.069 & 0.074 & 0.044 & 0.076 & 0.083 & & 200 & & 323 & 0.080 & 0.083 & 0.040 & 0.087 \\
\hline Austria & 0.050 & 0.059 & -0.080 & 0.055 & 0.077 & 0.09 & 19 & 19 & 42 & 0.072 & 0.076 & -0.082 & 0.072 \\
\hline Belgium & 0.100 & 0.110 & -0.024 & 0.108 & 0.068 & 0.10 & 26 & 19 & 57 & 0.103 & 0.112 & -0.049 & 0.113 \\
\hline Canada & 0.088 & 0.091 & $0.127 * * *$ & 0.100 & 0.125 & & 136 & & 329 & 0.109 & 0.117 & $0.107^{*}$ & 0.126 \\
\hline Denmark & 0.125 & 0.131 & -0.030 & 0.128 & 0.144 & 0.18 & 26 & 18 & 27 & 0.125 & 0.131 & -0.031 & 0.128 \\
\hline Finland & 0.255 & 0.258 & -0.026 & 0.254 & 0.234 & 0.26 & 27 & 24 & 31 & 0.281 & 0.283 & -0.031 & 0.278 \\
\hline France & 0.124 & 0.131 & $0.083^{-} * *$ & 0.123 & 0.095 & 0.12 & 103 & 36 & 232 & 0.130 & 0.141 & $-0.116 * *$ & 0.132 \\
\hline Germany & 0.060 & 0.076 & $-0.052 * *$ & 0.073 & 0.105 & 0.13 & 90 & 30 & 160 & 0.078 & 0.089 & $-0.060 *$ & 0.085 \\
\hline Greece & 0.078 & 0.083 & -0.064 & 0.078 & 0.085 & 0.06 & 24 & 19 & 37 & 0.076 & 0.082 & -0.037 & 0.081 \\
\hline India & 0.051 & 0.052 & 0.035 & 0.053 & 0.048 & & 53 & & 139 & 0.055 & 0.056 & -0.076 & 0.058 \\
\hline Ireland & 0.072 & 0.079 & -0.004 & 0.079 & 0.091 & 0.08 & 16 & 19 & 69 & 0.090 & 0.093 & $-0.060 * * *$ & 0.090 \\
\hline Italy & 0.057 & 0.055 & -0.047 & 0.053 & 0.034 & 0.05 & 56 & 38 & 93 & 0.036 & 0.038 & -0.043 & 0.038 \\
\hline Netherlands & 0.074 & 0.083 & 0.033 & 0.086 & 0.137 & 0.15 & 30 & 21 & 75 & 0.108 & 0.119 & 0.038 & 0.111 \\
\hline Norway & 0.379 & 0.371 & 0.033 & 0.379 & 0.343 & 0.39 & 23 & 16 & 57 & 0.406 & 0.391 & 0.054 & 0.400 \\
\hline Portugal & 0.051 & 0.055 & $0.112^{-} * * *$ & 0.050 & 0.018 & 0.05 & 11 & 19 & 25 & 0.025 & 0.028 & $-0.084 * * *$ & 0.027 \\
\hline Spain & 0.102 & 0.107 & -0.038 & 0.104 & 0.080 & 0.10 & 46 & 34 & 57 & 0.108 & 0.111 & -0.044 & 0.109 \\
\hline Sweden & 0.233 & 0.233 & 0.046 & 0.240 & 0.239 & 0.26 & 49 & 26 & 95 & 0.249 & 0.256 & -0.030 & 0.251 \\
\hline Switzerland & 0.067 & 0.078 & $-0.063 * *$ & 0.074 & 0.092 & & 51 & & 92 & 0.087 & 0.088 & $-0.080 * * *$ & 0.084 \\
\hline United Kingdom & 0.060 & 0.065 & $0.054 * *$ & 0.068 & 0.085 & 0.13 & 405 & 49 & 1,243 & 0.084 & 0.088 & 0.024 & 0.091 \\
\hline United States & 0.086 & 0.093 & $0.061 * * *$ & 0.097 & 0.122 & & 1,754 & & 4,098 & 0.114 & 0.115 & $0.062 * * *$ & 0.121 \\
\hline
\end{tabular}




\section{Table VII: Female Non-Executive Director Participation and Various Measures of Female Labor Force Participation}

This table shows the results of pooled cross-sectional OLS regressions of female non-executive director participation on country and policy characteristics for 20 countries in our representative sample, excluding Norway. Female non-executive director participation is measured as the number of unique female non-executive directors in a given year and country, over all unique non-executive directors for that year and country. The regressions vary by the measure of female labor force participation rates, which are all lagged by 10 years. Female Labor Force Participation is the classical participation measure defined as female labor force (employed + unemployed) over female population. Female Labor Force Participation (adj.) differs from the former that it excludes part-time workers. Female Economic Participation is calculated as female labor force over the total labor force; with the corresponding adjusted measure excluding part-time employment and unemployment from the numerator. Female Fulltime Economic Participation (adj.) is full-time female employment over full-time employment. In addition to year dummies, all regressions in Panel A include the following control variables whose coefficients are not reported and which are described in more detail in Table III: Codetermination, GNI per Capita lagged by 10 years, the birth rate lagged by 10 years, Tax \& Social Security as a percentage of gross income lagged by 10 years, Fraction of Family Firms per given and year and country, Fraction of Women in Higher Education (lagged), Wage Equality, Traditional vs. secular and survival vs. self-expression, Quota, Quota for State-owned Companies and Corporate Governance Code. Regressions in Panel B do not include any controls. Robust standard errors are clustered on country level. T-statistics are shown in brackets, and asterisks indicate significance at $0.01(* * *), 0.05(* *)$, and $0.10(*)$ levels.

\begin{tabular}{|c|c|c|c|c|c|}
\hline \multirow[t]{2}{*}{ Independent Variable } & \multicolumn{5}{|c|}{$\begin{array}{c}\text { Panel A: Dependent Variable: Female Non-Executive Director } \\
\text { Participation }\end{array}$} \\
\hline & $(1)$ & $(2)$ & $(3)$ & (4) & $(5)$ \\
\hline Female Labor Force Participation (lagged) & $\begin{array}{c}0.074 \\
{[0.570]}\end{array}$ & & & & \\
\hline Female Labor Force Participation (adj.) (lagged) & & $\begin{array}{c}0.397 * * * \\
{[4.194]}\end{array}$ & & & \\
\hline Female Economic Participation (lagged) & \multicolumn{5}{|c|}{$\begin{array}{l}0.270 \\
{[1.255]}\end{array}$} \\
\hline Female Economic Participation (adj.) (lagged) & & & \multicolumn{3}{|c|}{$\begin{array}{l}0.416^{* * *} \\
{[4.083]}\end{array}$} \\
\hline Female Fulltime Economic Participation (lagged) & & & & & $\begin{array}{l}0.474 * * * \\
{[4.754]}\end{array}$ \\
\hline Full Set of Controls & Yes & Yes & Yes & Yes & Yes \\
\hline Time Dummies & Yes & Yes & Yes & Yes & Yes \\
\hline Observations & 153 & 153 & 153 & 153 & 153 \\
\hline \multirow[t]{3}{*}{ R-squared } & 0.786 & 0.870 & 0.798 & 0.868 & 0.875 \\
\hline & \multicolumn{5}{|c|}{$\begin{array}{c}\text { Panel B: Dependent Variable: Female Non-Executive Director } \\
\text { Participation }\end{array}$} \\
\hline & $(1)$ & $(2)$ & $(3)$ & (4) & $(5)$ \\
\hline Female Labor Force Participation (lagged) & $\begin{array}{c}0.372 * * * \\
{[2.942]}\end{array}$ & & & & \\
\hline Female Labor Force Participation (adj.) (lagged) & & $\begin{array}{l}0.502 * * \\
{[2.614]}\end{array}$ & & & \\
\hline Female Economic Participation (lagged) & & & $\begin{array}{l}0.670 * * \\
{[2.496]}\end{array}$ & & \\
\hline Female Economic Participation (adj.) (lagged) & & & & $\begin{array}{l}0.496 * \\
{[1.902]}\end{array}$ & \\
\hline Female Fulltime Economic Participation (lagged) & & & & & $\begin{array}{l}0.568 * * \\
{[2.622]}\end{array}$ \\
\hline Controls & No & No & No & No & No \\
\hline Time Dummies & No & No & No & No & No \\
\hline Observations & 153 & 153 & 153 & 153 & 153 \\
\hline R-squared & 0.260 & 0.352 & 0.291 & 0.251 & 0.351 \\
\hline
\end{tabular}




\section{Table VIII: Female Non-Executive Director Participation and Other Factors}

This table shows the results of pooled cross-sectional OLS regressions of female non-executive director participation in the boardroom on country and policy characteristics for 20 countries in our representative sample, excluding Norway. Female Fulltime Economic Participation (adj.) is as described in Table VII, and lagged by 10 years. Codetermination is a dummy variable as described in Table 1. GNI per Capita denotes the gross national income per capita in USD in constant 2011 prices and exchange rates, and is lagged by 10 years. We define a Family Firm to be a firm in which two or more directors have the same last name, and when data is available, the fraction of closely held shares is more than $20 \%$. Wage equality is the average of 2006-10 figures as collected by the World Economic Forum. The birth rate gives the number of births per 1000 inhabitants, and is lagged by 10 years. Tax \& Social Security measures the percentage of tax and social security as percentage of gross income; it is again lagged by 10 years. Traditional vs. secular and survival vs. selfexpression measure cultural dimensions and are based on Inglehart and Welzel (2005). Quota and Quota for State-owned Companies are dummy variables identifying whether for a given year and country a formal board quota was in place for all or state-owned companies respectively, Corporate Governance Code is a dummy indicating whether gender balance was explicitly stated in the governance code. Robust standard errors are clustered on country level. T-statistics are shown in brackets, and asterisks indicate significance at $0.01(* *), 0.05(* *)$, and $0.10(*)$ levels. Economic Magnitude is calculated as coefficient times standard deviation.

Independent Variable

Dependent Variable:

Econ.

Female Non-Executive Director Participation

(1)

(2)

(3)

(4)

(5)

Magn.

Female Fulltime Economic

$\begin{array}{cccccc}0.556^{* * *} & 0.630 * * * & 0.590^{* * *} & 0.466^{* * *} & 0.474 * * * & 0.026 \\ {[3.448]} & {[3.741]} & {[3.676]} & {[3.728]} & {[4.754]} & \\ 0.028^{* *} & 0.016 & 0.017 & 0.004 & 0.001 & 0.000 \\ {[2.180]} & {[1.587]} & {[1.577]} & {[0.458]} & {[0.072]} & \\ 0.000 & 0.000 & 0.000 & -0.000 & 0.000 & 0.000 \\ {[0.280]} & {[0.082]} & {[0.134]} & {[-0.010]} & {[1.098]} & \\ -0.113^{*} & -0.076 & -0.051 & -0.065 & -0.082 * * & -0.013 \\ {[-2.022]} & {[-1.699]} & {[-0.803]} & {[-1.568]} & {[-2.874]} & \\ -0.091 & -0.316^{*} & -0.315 * & -0.043 & 0.021 & 0.001 \\ {[-0.734]} & {[-1.804]} & {[-1.763]} & {[-0.498]} & {[0.339]} & \\ & 0.002 & 0.001 & 0.003 * & 0.004 * * * & 0.011 \\ & {[1.034]} & {[0.564]} & {[1.901]} & {[3.587]} & \\ & 0.002 * * & 0.002 * * & 0.002 * * * & 0.001 * * * & 0.009 \\ & {[2.410]} & {[2.486]} & {[3.049]} & {[3.302]} & \\ & & 0.013 & 0.017 & 0.022^{* *} & 0.012 \\ & & {[0.885]} & {[1.663]} & {[2.394]} & \\ & & & 0.034 * * * & 0.033^{* * *} & 0.025 \\ & & & {[4.436]} & {[5.327]} & \\ & & & -0.015 & -0.027 * * & -0.016\end{array}$

Quota

$-0.001$

Quota for State-owned Companies

$[-0.057]$

Corporate Governance Code

[3.280]

\begin{tabular}{lccccc}
\hline Year Dummies & Yes & Yes & Yes & Yes & Yes \\
Observations & 155 & 153 & 153 & 153 & 153 \\
R-squared & 0.548 & 0.669 & 0.680 & 0.811 & 0.875 \\
\hline
\end{tabular}




\section{Table IX: Female Non-Executive Director Participation - Robustness I}

This table shows the results of pooled cross-sectional OLS regressions of female non-executive director participation in the boardroom on country and policy characteristics. (1) 19 countries excluding Norway and India. (2) 18 countries excluding USA, Norway and India (3) for 21 countries, including USA, Norway and India. All variables are as in Table VIII. Robust standard errors are clustered on country level. T-statistics are shown in brackets, and asterisks indicate significance at $0.01(* * *), 0.05(* *)$, and $0.10(*)$ levels.

\begin{tabular}{|c|c|c|c|}
\hline \multirow[t]{2}{*}{ Independent Variable } & \multicolumn{3}{|c|}{$\begin{array}{c}\text { Dependent Variable: } \\
\text { Female Non-Executive Director Participation }\end{array}$} \\
\hline & $(1)$ & $(2)$ & (3) \\
\hline Female Fulltime Economic & $0.457 * * *$ & $0.450 * * *$ & $0.458 * * *$ \\
\hline Participation (lagged) & {$[4.921]$} & {$[4.246]$} & {$[4.152]$} \\
\hline \multirow[t]{2}{*}{ Codetermination } & 0.008 & 0.009 & 0.003 \\
\hline & {$[0.918]$} & {$[0.960]$} & {$[0.328]$} \\
\hline \multirow[t]{2}{*}{ GNI / Capita (lagged) } & $0.000 * * *$ & $0.000 * * *$ & $0.000 * *$ \\
\hline & {$[3.341]$} & {$[3.354]$} & {$[2.220]$} \\
\hline \multirow[t]{2}{*}{ Fraction of Family Firms } & $-0.106 * * *$ & $-0.104 * * *$ & $-0.082 * * *$ \\
\hline & {$[-3.978]$} & {$[-4.113]$} & {$[-2.873]$} \\
\hline Fraction of Women in Higher & $0.146 * *$ & $0.144 * *$ & 0.121 \\
\hline Education (lagged) & {$[2.265]$} & {$[2.347]$} & [1.119] \\
\hline \multirow[t]{2}{*}{ Birth Rate (lagged) } & -0.002 & -0.002 & $0.005 * * *$ \\
\hline & {$[-0.462]$} & {$[-0.472]$} & {$[4.650]$} \\
\hline \multirow[t]{2}{*}{ Tax \& Social Security (lagged) } & $0.002 * * *$ & $0.002 * * *$ & $0.001 * *$ \\
\hline & {$[4.098]$} & {$[3.726]$} & {$[2.750]$} \\
\hline \multirow[t]{2}{*}{ Wage Equality } & $0.023^{*}$ & $0.024^{*}$ & $0.030 * * *$ \\
\hline & {$[2.073]$} & {$[2.061]$} & {$[3.573]$} \\
\hline \multirow[t]{2}{*}{ Traditional vs. Secular Values } & $0.024 * * *$ & $0.025 * *$ & $0.035 * * *$ \\
\hline & {$[2.945]$} & {$[2.792]$} & {$[6.036]$} \\
\hline \multirow[t]{2}{*}{ Survival vs. Self-expression Values } & $-0.022 * *$ & $-0.022 * *$ & $-0.039 * * *$ \\
\hline & {$[-2.228]$} & {$[-2.240]$} & {$[-3.319]$} \\
\hline \multirow[t]{2}{*}{ Quota } & $0.049 * * *$ & $0.048 * * *$ & $0.081 * * *$ \\
\hline & {$[3.713]$} & {$[3.585]$} & {$[3.535]$} \\
\hline \multirow[t]{2}{*}{ Quota for State-owned Companies } & 0.001 & 0.001 & -0.007 \\
\hline & {$[0.077]$} & {$[0.089]$} & {$[-0.519]$} \\
\hline \multirow[t]{2}{*}{ Corporate Governance Code } & $0.029 * * *$ & $0.030 * * *$ & $0.033 * * *$ \\
\hline & {$[4.004]$} & [3.891] & [3.532] \\
\hline Year dummies & Yes & Yes & Yes \\
\hline Observations & 150 & 143 & 163 \\
\hline R-squared & 0.885 & 0.887 & 0.874 \\
\hline
\end{tabular}




\section{Table X: Female Non-Executive Director Participation - Robustness II}

This table shows the results of pooled cross-sectional OLS regressions of female non-executive director participation in the boardroom on country and policy characteristics. All regressions are based on an unrestricted sample, and a full set of control variables. Regression (1) differs from previous regressions in Table VIII, that wage equality is substituted for the skilled labor pay gap variable as calculated by Olivetti and Petrongolo (2011). (2) Differs by replacing our measure for family firms with the results from Faccio Lang (2006) as described in Table III - Panel A. (3) substitutes taxation level with the services component of family benefits as published by the OECD (2007). (4) differs from (3) that it denotes the level of tax breaks families receive. Summary statistics for alternate measures are in the Appendix. Robust standard errors are clustered on country level. T-statistics are shown in brackets, and asterisks indicate significance at $0.01(* * *)$, $0.05(* *)$, and $0.10(*)$ levels.

\begin{tabular}{|c|c|c|c|c|}
\hline \multirow[t]{2}{*}{ Independent Variable } & \multicolumn{4}{|c|}{$\begin{array}{c}\text { Dependent Variable: } \\
\text { Female Non-Executive Director Participation }\end{array}$} \\
\hline & $(1)$ & (2) & (3) & (4) \\
\hline Female Fulltime Economic & $0.404 * *$ & 0.369 & $0.408 * * *$ & $0.373 * * *$ \\
\hline Participation (lagged) & {$[2.555]$} & {$[1.142]$} & {$[4.155]$} & [4.489] \\
\hline Codetermination & $\begin{array}{l}-0.005 \\
{[-0.560]}\end{array}$ & $\begin{array}{c}0.035 * * * \\
{[5.555]}\end{array}$ & $\begin{array}{c}0.010 \\
{[0.762]}\end{array}$ & $\begin{array}{l}0.008 \\
{[0.674]}\end{array}$ \\
\hline GNI / Capita (lagged) & $\begin{array}{l}0.000^{* *} \\
{[2.267]}\end{array}$ & $\begin{array}{l}0.000^{*} \\
{[2.033]}\end{array}$ & $\begin{array}{c}0.000 \\
{[0.860]}\end{array}$ & $\begin{array}{l}0.000 \\
{[0.008]}\end{array}$ \\
\hline Fraction of Family Firms & $\begin{array}{c}-0.133 * * * \\
{[-5.449]}\end{array}$ & & $\begin{array}{c}-0.115^{* * *} \\
{[-3.378]}\end{array}$ & $\begin{array}{c}-0.099 * * \\
{[-2.690]}\end{array}$ \\
\hline Fraction of Women in Higher & -0.009 & 0.253 & 0.123 & 0.151 \\
\hline Education (lagged) & {$[-0.052]$} & [1.791] & {$[0.817]$} & [0.946] \\
\hline Birth Rate (lagged) & $\begin{array}{c}0.006 \\
{[0.934]}\end{array}$ & $\begin{array}{c}0.000 \\
{[0.106]}\end{array}$ & $\begin{array}{c}-0.005 \\
{[-1.147]}\end{array}$ & $\begin{array}{c}0.001 \\
{[0.300]}\end{array}$ \\
\hline Tax \& Social Security (lagged) & $\begin{array}{c}0.001 \\
{[0.908]}\end{array}$ & $\begin{array}{l}0.002 * * \\
{[2.787]}\end{array}$ & & \\
\hline Wage Equality & & $\begin{array}{l}0.020^{* *} \\
{[2.380]}\end{array}$ & $\begin{array}{l}0.027 * * \\
{[2.548]}\end{array}$ & $\begin{array}{c}0.016 \\
{[1.485]}\end{array}$ \\
\hline Traditional vs. Secular Values & $\begin{array}{c}0.014 \\
{[0.986]}\end{array}$ & $\begin{array}{c}0.051 * * * \\
{[6.704]}\end{array}$ & $\begin{array}{c}0.012 \\
{[1.034]}\end{array}$ & $\begin{array}{r}0.036^{* * *} \\
{[4.478]}\end{array}$ \\
\hline Survival vs. Self-expression Values & $\begin{array}{l}-0.039 * * \\
{[-2.234]}\end{array}$ & $\begin{array}{c}-0.064 \\
{[-1.400]}\end{array}$ & $\begin{array}{c}-0.009 \\
{[-0.556]}\end{array}$ & $\begin{array}{c}-0.005 \\
{[-0.254]}\end{array}$ \\
\hline Quota & $\begin{array}{c}0.062 * * * \\
{[3.122]}\end{array}$ & $\begin{array}{l}0.042 * * \\
{[2.662]}\end{array}$ & $\begin{array}{c}0.096 * * * \\
{[3.703]}\end{array}$ & $\begin{array}{r}0.089 * * * \\
{[3.296]}\end{array}$ \\
\hline Quota for State-owned Companies & $\begin{array}{l}0.032 * \\
{[2.126]}\end{array}$ & $\begin{array}{c}0.015 \\
{[0.375]}\end{array}$ & $\begin{array}{c}0.002 \\
{[0.122]}\end{array}$ & $\begin{array}{c}0.014 \\
{[0.659]}\end{array}$ \\
\hline Corporate Governance Code & $\begin{array}{c}0.020 * * * \\
{[3.087]}\end{array}$ & $\begin{array}{l}0.029 * * \\
{[2.466]}\end{array}$ & $\begin{array}{l}0.024 * * \\
{[2.455]}\end{array}$ & $\begin{array}{l}0.027^{* *} \\
{[2.444]}\end{array}$ \\
\hline $\begin{array}{l}\text { Skilled Labor Pay Gap - Olivetti } \\
\text { Petrongolo }\end{array}$ & $\begin{array}{c}-0.000 \\
{[-0.264]}\end{array}$ & & & \\
\hline Family Firms - Faccio Lang & & $\begin{array}{c}-0.002 \\
{[-1.607]}\end{array}$ & & \\
\hline Family Benefits - Services & & & $\begin{array}{l}0.033 * * \\
{[2.283]}\end{array}$ & \\
\hline Family Benefits - Tax breaks & & & & $\begin{array}{c}-0.008 \\
{[-0.636]}\end{array}$ \\
\hline Year dummies & Yes & Yes & Yes & Yes \\
\hline Observations & 123 & 107 & 162 & 155 \\
\hline R-squared & 0.868 & 0.920 & 0.851 & 0.845 \\
\hline
\end{tabular}




\section{Table XI: Female Non-Executive Director Participation - Robustness III}

This table shows the results of pooled cross-section OLS regressions of female non-executive director participation in the boardroom on country and policy characteristics. All regressions are based on a full set of control variables, and exclude Norway. All variables are as described in Table VIII, except that we exclude Traditional vs. Secular Values and Survival vs. Self-expression Values. Instead, we use Women Housewife, Child Independence and Women's Rights from the WVS. Summary statistics for alternate measures are in the Appendix. Robust standard errors are clustered on country level. T-statistics are shown in brackets, and asterisks indicate significance at $0.01(* * *), 0.05(* *)$, and $0.10(*)$ levels.

\begin{tabular}{|c|c|c|c|c|}
\hline \multirow[t]{2}{*}{ Independent Variable } & \multicolumn{4}{|c|}{$\begin{array}{c}\text { Dependent Variable: } \\
\text { Female Non-Executive Director Participation }\end{array}$} \\
\hline & $(1)$ & (2) & (3) & (4) \\
\hline $\begin{array}{l}\text { Female Fulltime Economic } \\
\text { Participation (lagged) }\end{array}$ & $\begin{array}{c}0.427 * * * \\
{[4.809]}\end{array}$ & $\begin{array}{c}0.495 * * * \\
{[6.505]}\end{array}$ & $\begin{array}{l}0.621 * * * \\
{[23.637]}\end{array}$ & $\begin{array}{c}0.506^{* * *} \\
{[5.787]}\end{array}$ \\
\hline Codetermination & $\begin{array}{c}0.026 * * * \\
{[3.196]}\end{array}$ & $\begin{array}{c}0.035^{* * *} \\
{[4.820]}\end{array}$ & $\begin{array}{l}0.043 * * * \\
{[15.974]}\end{array}$ & $\begin{array}{c}0.040^{* * *} \\
{[4.435]}\end{array}$ \\
\hline GNI / Capita (lagged) & $\begin{array}{l}0.000^{* *} \\
{[2.452]}\end{array}$ & $\begin{array}{l}0.000^{*} \\
{[1.858]}\end{array}$ & $\begin{array}{l}0.000 * * \\
{[2.910]}\end{array}$ & $\begin{array}{c}0.000 \\
{[1.604]}\end{array}$ \\
\hline Fraction of Family Firms & $\begin{array}{l}0.116^{*} \\
{[2.091]}\end{array}$ & $\begin{array}{c}0.126^{* * *} \\
{[3.610]}\end{array}$ & $\begin{array}{l}0.038^{* *} \\
{[2.457]}\end{array}$ & $\begin{array}{c}0.134 * * * \\
{[3.883]}\end{array}$ \\
\hline Fraction of Women in Higher & $\begin{array}{l}-0.040 \\
{[-0.378]}\end{array}$ & $\begin{array}{l}-0.004 \\
{[-0.056]}\end{array}$ & $\begin{array}{c}-0.141 * * * \\
{[-5891]}\end{array}$ & $\begin{array}{l}-0.007 \\
{[-0.086]}\end{array}$ \\
\hline Birth Rate (lagged) & $\begin{array}{c}0.002 \\
{[1.614]}\end{array}$ & $\begin{array}{l}0.002 * * \\
{[2.980]}\end{array}$ & $\begin{array}{l}0.008 * * * \\
{[14.181]}\end{array}$ & $\begin{array}{l}0.002 * * \\
{[2.742]}\end{array}$ \\
\hline Tax \& Social Security (lagged) & $\begin{array}{c}0.001 * * * \\
{[3.363]}\end{array}$ & $\begin{array}{c}0.002 * * * \\
{[3.800]}\end{array}$ & $\begin{array}{c}0.001 * * * \\
{[6.774]}\end{array}$ & $\begin{array}{c}0.002^{* * *} \\
{[3.731]}\end{array}$ \\
\hline Wage Equality & $\begin{array}{c}0.055 * * * \\
{[4.363]}\end{array}$ & $\begin{array}{c}0.026 * * * \\
{[3.337]}\end{array}$ & $\begin{array}{l}0.011^{*} \\
{[1.938]}\end{array}$ & $\begin{array}{l}0.022 * * \\
{[2.583]}\end{array}$ \\
\hline Quota & $\begin{array}{c}0.011 \\
{[0.741]}\end{array}$ & $\begin{array}{c}0.040 * * * \\
{[4.445]}\end{array}$ & $\begin{array}{c}0.033 * * * \\
{[6.813]}\end{array}$ & $\begin{array}{c}0.044 * * * \\
{[5.291]}\end{array}$ \\
\hline Quota for State-owned Companies & $\begin{array}{c}0.077 * * * \\
{[3.716]}\end{array}$ & $\begin{array}{c}0.040 * * * \\
{[5.266]}\end{array}$ & $\begin{array}{c}0.039 * * * \\
{[11.565]}\end{array}$ & $\begin{array}{c}0.028 \\
{[1.385]}\end{array}$ \\
\hline Corporate Governance Code & $\begin{array}{c}0.017 \\
{[1.743]}\end{array}$ & $\begin{array}{c}0.014^{*} \\
{[1.842]}\end{array}$ & $\begin{array}{c}0.008 \\
{[1.681]}\end{array}$ & $\begin{array}{l}0.014 * \\
{[1.924]}\end{array}$ \\
\hline WVS: "Women housewife" & $\begin{array}{c}-0.058 * * \\
{[-2.782]}\end{array}$ & & & $\begin{array}{c}0.020 \\
{[0.847]}\end{array}$ \\
\hline WVS: "Child independence" & & $\begin{array}{c}0.158 * * * \\
{[5.542]}\end{array}$ & & $\begin{array}{c}0.186^{* * *} \\
{[4.331]}\end{array}$ \\
\hline WVS: "Women rights" & & & $\begin{array}{l}0.081 * * * \\
{[14.333]} \\
\end{array}$ & \\
\hline Year dummies & Yes & Yes & Yes & Yes \\
\hline Observations & 83 & 83 & 68 & 83 \\
\hline R-squared & 0.943 & 0.957 & 0.976 & 0.958 \\
\hline
\end{tabular}




\section{Table XII: Female Non-Executive Director Participation - IV Regression}

This table shows the results of a 2SLS instrumental variable (IV) regression. Column (1) reports the first stage, with Alternative Employment Contracts ('index_altern12' in Botero et al. (2004)) and Latitude ('lat_abst' in LaPorta et al. (2004)) as an instrument for Female Fulltime Economic Participation. Column (2) reports the results of the IV estimation, with (3) reporting the economic magnitude of its coefficients. The economic magnitude is calculated as coefficient times standard deviation. All other variables are as Table VIII. Summary statistics for instruments are in the Appendix. Robust standard errors are clustered on country level. T-statistics are shown in brackets, and asterisks indicate significance at $0.01(* * *), 0.05(* *)$, and $0.10(*)$ levels.

\begin{tabular}{|c|c|c|c|}
\hline \multirow[t]{6}{*}{ Independent Variable } & \multicolumn{2}{|c|}{ Dependent Variable } & \multirow{5}{*}{$\begin{array}{l}\text { Economic } \\
\text { Magnitude }\end{array}$} \\
\hline & Female & Female & \\
\hline & Fulltime & Executive & \\
\hline & Economic & Director & \\
\hline & Participation & Participation & \\
\hline & $(1)$ & $(2)$ & $(3)$ \\
\hline Female Fulltime Economic & & $0.616^{* * *}$ & 0.034 \\
\hline Participation (lagged) & & {$[7.86]$} & \\
\hline \multirow[t]{2}{*}{ Tax \& Social Security (lagged) } & $-0.004 * * *$ & $0.002 * * *$ & 0.018 \\
\hline & {$[-9.05]$} & {$[6.70]$} & \\
\hline \multirow[t]{2}{*}{ Wage Equality } & $-0.038 * *$ & $0.022 * *$ & 0.012 \\
\hline & {$[-2.22]$} & {$[2.28]$} & \\
\hline \multirow[t]{2}{*}{ Traditional vs. Secular Values } & -0.013 & $0.032 * * *$ & 0.024 \\
\hline & {$[-1.23]$} & {$[4.66]$} & \\
\hline \multirow[t]{2}{*}{ Survival vs. Self-expression Values } & $0.067 * * *$ & $-0.032 * * *$ & -0.019 \\
\hline & {$[3.40]$} & {$[-3.66]$} & \\
\hline \multirow[t]{2}{*}{ Quota } & $-0.043^{*}$ & $0.051 * * *$ & \\
\hline & {$[-1.93]$} & {$[3.28]$} & \\
\hline \multirow[t]{2}{*}{ Quota for State-owned Companies } & $0.038 * * *$ & -0.006 & \\
\hline & {$[3.02]$} & {$[-0.65]$} & \\
\hline \multirow[t]{2}{*}{ Corporate Governance Code } & 0.010 & $0.030 * * *$ & \\
\hline & {$[0.98]$} & {$[3.05]$} & \\
\hline \multirow[t]{2}{*}{ Alternative Employment Contract } & $0.264 * * *$ & & \\
\hline & {$[4.80]$} & & \\
\hline \multirow[t]{2}{*}{ Latitude } & $0.270 * * *$ & & \\
\hline & {$[5.40]$} & & \\
\hline Year Dummies & Yes & Yes & \\
\hline Observations & 153 & 153 & \\
\hline R-squared & 0.707 & 0.775 & \\
\hline Kleibergen-Paap Wald statistic & 29.13 & & \\
\hline \multirow[t]{2}{*}{ Hansen J statistic } & & 0.301 & \\
\hline & & (p: 0.583$)$ & \\
\hline Regression & First Stage IV & IV & \\
\hline
\end{tabular}




\section{Table XIII: Female Executive Director Participation and Measures of Female Labor Force Participation}

This table shows the results of pooled cross-sectional OLS regressions of female executive director participation on country and policy characteristics for 20 countries in our representative sample, excluding Norway. Female non-executive director participation is measured as the number of unique female non-executive directors in a given year and country, over all unique non-executive directors for that year and country. The regressions vary by the measure of female labor force participation rates, which are all lagged by 10 years. Female Labor Force Participation is the classical participation measure defined as female labor force (employed + unemployed) over female population. Female Labor Force Participation (adj.) differs from the former that it excludes part-time workers. Female Economic Participation is calculated as female labor force over the total labor force; with the corresponding adjusted measure excluding part-time employment and unemployment from the numerator. Female Fulltime Economic Participation (adj.) is full-time female employment over full-time employment. In addition to year dummies, all regressions in Panel A include the following control variables whose coefficients are not reported and which are described in more detail in Table III: Codetermination, GNI per Capita lagged by 10 years, the birth rate lagged by 10 years, Tax \& Social Security as a percentage of gross income lagged by 10 years, Fraction of Family Firms per given and year and country, Fraction of Women in Higher Education (lagged), Wage Equality, Traditional vs. secular and survival vs. selfexpression, Quota, Quota for State-owned Companies and Corporate Governance Code. Regressions in Panel B do not include any controls. Robust standard errors are clustered on country level. T-statistics are shown in brackets, and asterisks indicate significance at $0.01(* * *), 0.05(* *)$, and $0.10(*)$ levels.

\begin{tabular}{|c|c|c|c|c|c|}
\hline \multirow[t]{2}{*}{ Independent Variable } & \multicolumn{5}{|c|}{ Panel A: Dependent Variable: Female Executive Director Participation } \\
\hline & $(1)$ & $(2)$ & $(3)$ & $(4)$ & $(5)$ \\
\hline Female Labor Force Participation (lagged) & $\begin{array}{c}0.073 \\
{[1.579]}\end{array}$ & & & & \\
\hline Female Labor Force Participation (adj.) (lagged) & & $\begin{array}{c}0.082 * \\
{[1.781]}\end{array}$ & & & \\
\hline Female Economic Participation (lagged) & & & $\begin{array}{c}0.238 * * \\
{[2.726]}\end{array}$ & & \\
\hline Female Economic Participation (adj.) (lagged) & & & & $\begin{array}{c}0.093^{*} \\
{[1.770]}\end{array}$ & \\
\hline Female Fulltime Economic Participation (lagged) & & & & & $\begin{array}{l}0.133 * \\
{[2.095]}\end{array}$ \\
\hline Full Set of Controls & Yes & Yes & Yes & Yes & Yes \\
\hline Time Dummies & Yes & Yes & Yes & Yes & Yes \\
\hline Observations & 153 & 153 & 153 & 153 & 153 \\
\hline R-squared & 0.498 & 0.501 & 0.519 & 0.502 & 0.509 \\
\hline
\end{tabular}

Panel B: Dependent Variable: Female Non-Executive Director Participation

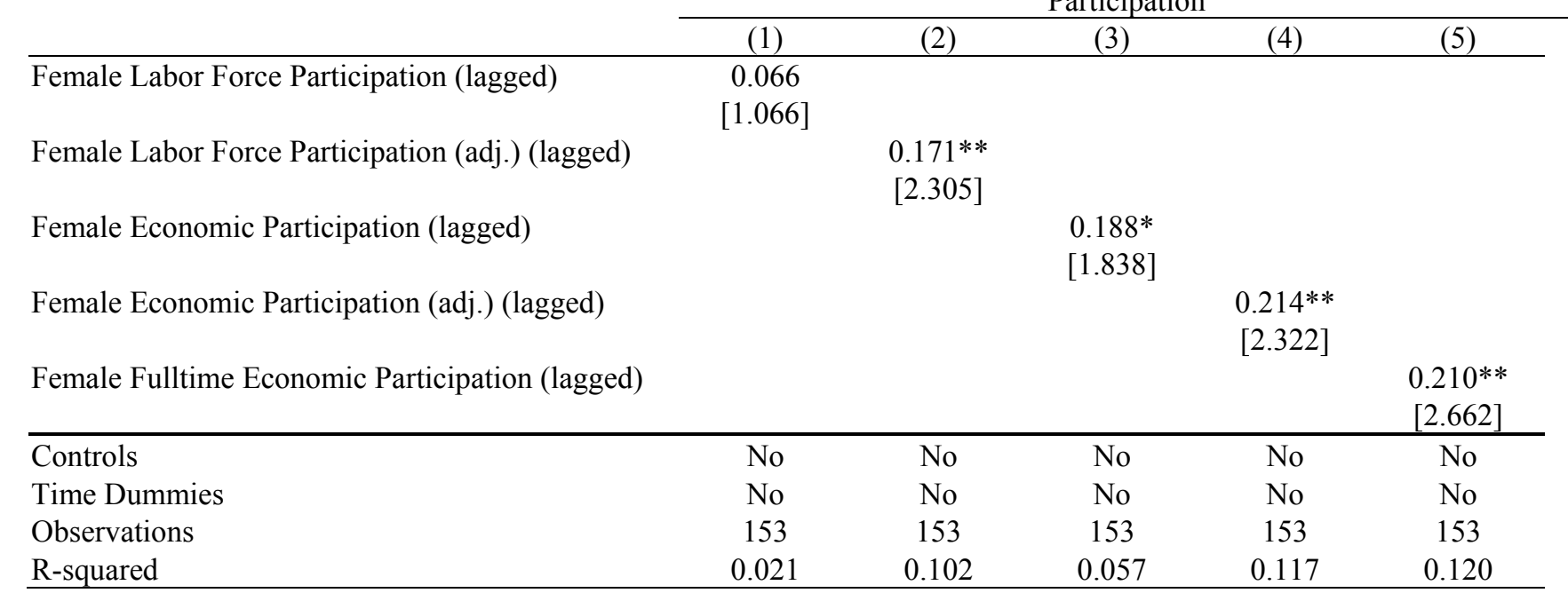




\section{Table XIV: Female Executive Director Participation}

This table shows the results of pooled cross-section OLS regressions of female executive director participation in the boardroom on country and policy characteristics for 20 countries, excluding Norway. All other variables are as in Table VIII. Robust standard errors are clustered on country level. T-statistics are shown in brackets, and asterisks indicate significance at $0.01(* * *), 0.05(* *)$, and $0.10(*)$ levels.

\begin{tabular}{|c|c|c|c|c|c|c|}
\hline \multirow[t]{2}{*}{ Independent Variable } & \multicolumn{5}{|c|}{$\begin{array}{c}\text { Dependent Variable: } \\
\text { Female Executive Director Participation }\end{array}$} & \multirow{2}{*}{$\begin{array}{c}\text { Economic } \\
\text { Magnitude }\end{array}$} \\
\hline & $(1)$ & $(2)$ & $(3)$ & $(4)$ & $(5)$ & \\
\hline Female Fulltime Economic & $0.212 * *$ & $0.233^{* *}$ & $0.223^{* *}$ & $0.261 * * *$ & $0.133^{*}$ & 0.007 \\
\hline Participation (lagged) & {$[2.190]$} & {$[2.274]$} & {$[2.367]$} & {$[5.211]$} & [2.095] & \\
\hline \multirow{2}{*}{ Codetermination } & 0.002 & -0.002 & -0.002 & -0.008 & -0.011 & -0.005 \\
\hline & {$[0.300]$} & {$[-0.387]$} & {$[-0.378]$} & {$[-1.088]$} & {$[-1.649]$} & \\
\hline \multirow[t]{2}{*}{ GNI / Capita (lagged) } & -0.000 & -0.000 & -0.000 & 0.000 & 0.000 & 0.000 \\
\hline & {$[-0.640]$} & {$[-0.602]$} & {$[-0.599]$} & [0.917] & {$[0.633]$} & \\
\hline \multirow[t]{2}{*}{ Fraction of Family Firms } & 0.009 & 0.024 & 0.031 & 0.004 & 0.005 & 0.001 \\
\hline & {$[0.365]$} & [1.123] & [1.157] & {$[0.153]$} & {$[0.261]$} & \\
\hline Fraction of Women in Higher & -0.023 & -0.114 & -0.114 & -0.025 & -0.010 & -0.001 \\
\hline Education (lagged) & {$[-0.315]$} & {$[-1.253]$} & {$[-1.241]$} & {$[-0.365]$} & {$[-0.140]$} & \\
\hline \multirow[t]{2}{*}{ Birth Rate (lagged) } & & 0.000 & -0.000 & 0.001 & 0.001 & 0.003 \\
\hline & & {$[0.165]$} & {$[-0.002]$} & {$[0.594]$} & {$[0.786]$} & \\
\hline \multirow[t]{2}{*}{ Tax \& Social Security (lagged) } & & 0.001 & 0.001 & $0.002 * * *$ & $0.001 * *$ & 0.009 \\
\hline & & [1.696] & [1.664] & {$[3.191]$} & {$[2.331]$} & \\
\hline \multirow[t]{2}{*}{ Wage equality } & & & 0.004 & 0.012 & -0.006 & -0.003 \\
\hline & & & [0.299] & [0.982] & {$[-0.496]$} & \\
\hline \multirow[t]{2}{*}{ Traditional vs. secular values } & & & & 0.002 & -0.006 & -0.005 \\
\hline & & & & {$[0.388]$} & {$[-1.089]$} & \\
\hline \multirow[t]{2}{*}{ Survival vs. self-expression values } & & & & $-0.033 * *$ & -0.012 & -0.007 \\
\hline & & & & {$[-2.519]$} & {$[-1.218]$} & \\
\hline \multirow[t]{2}{*}{ Quota } & & & & & -0.039 & \\
\hline & & & & & {$[-1.508]$} & \\
\hline \multirow[t]{2}{*}{ Quota for State-owned Companies } & & & & & $0.049 * * *$ & \\
\hline & & & & & {$[4.460]$} & \\
\hline \multirow[t]{2}{*}{ Corporate Governance Code } & & & & & 0.015 & \\
\hline & & & & & {$[0.622]$} & \\
\hline Year Dummies & Yes & Yes & Yes & Yes & Yes & \\
\hline Observations & 155 & 153 & 153 & 153 & 153 & \\
\hline R-squared & 0.238 & 0.286 & 0.288 & 0.348 & 0.509 & \\
\hline
\end{tabular}




\section{Table XV: Female Executive Director Participation - IV Regression}

This table shows the results of a 2SLS instrumental variable (IV) regression. Column (1) reports the first stage, with Alternative Employment Contracts ('index_altern12' in Botero et al. (2004)) and Latitude ('lat_abst' in LaPorta et al. (2004)) as an instrument for Female Fulltime Economic Participation. Column (2) reports the results of the IV estimation, with (3) reporting the economic magnitude of its coefficients. The economic magnitude is calculated as coefficient times standard deviation. All other variables are as Table VIII. Summary statistics for instruments are in the Appendix. Robust standard errors are clustered on country level. T-statistics are shown in brackets, and asterisks indicate significance at $0.01(* * *), 0.05(* *)$, and $0.10\left(^{*}\right)$ levels.

\begin{tabular}{|c|c|c|c|}
\hline \multirow[t]{6}{*}{ Independent Variable } & \multicolumn{2}{|c|}{ Dependent Variable } & \multirow{5}{*}{$\begin{array}{l}\text { Economic } \\
\text { Magnitude }\end{array}$} \\
\hline & Female & Female & \\
\hline & Fulltime & Executive & \\
\hline & Economic & Director & \\
\hline & Participation & Participation & \\
\hline & $(1)$ & (2) & (3) \\
\hline Female Fulltime Economic & & $0.295 * * *$ & 0.106 \\
\hline Participation (lagged) & & {$[2.83]$} & \\
\hline \multirow[t]{2}{*}{ Tax \& Social Security (lagged) } & $-0.004 * * *$ & $0.001 * *$ & 0.028 \\
\hline & {$[-9.05]$} & {$[2.42]$} & \\
\hline \multirow[t]{2}{*}{ Wage Equality } & $-0.038 * *$ & -0.006 & -0.026 \\
\hline & {$[-2.22]$} & {$[-0.55]$} & \\
\hline \multirow[t]{2}{*}{ Traditional vs. secular values } & -0.013 & -0.007 & -0.003 \\
\hline & {$[-1.23]$} & {$[-1.17]$} & \\
\hline \multirow[t]{2}{*}{ Survival vs. self-expression values } & $0.067 * * *$ & -0.018 & -0.023 \\
\hline & {$[3.40]$} & {$[-1.51]$} & \\
\hline \multirow[t]{2}{*}{ Quota } & $-0.043 *$ & -0.034 & \\
\hline & {$[-1.93]$} & {$[-1.28]$} & \\
\hline \multirow[t]{2}{*}{ Quota for State-owned Companies } & $0.038 * * *$ & $0.042 * * *$ & \\
\hline & [3.02] & {$[4.46]$} & \\
\hline \multirow[t]{2}{*}{ Corporate Governance Code } & 0.010 & 0.012 & \\
\hline & {$[0.98]$} & {$[0.55]$} & \\
\hline \multirow[t]{2}{*}{ Alternative Employment Contract } & $0.264 * * *$ & & \\
\hline & {$[4.80]$} & & \\
\hline \multirow[t]{2}{*}{ Latitude } & $0.270 * * *$ & & \\
\hline & {$[5.40]$} & & \\
\hline Year Dummies & 153 & 153 & \\
\hline Observations & Yes & Yes & \\
\hline R-squared & 0.707 & 0.425 & \\
\hline Kleibergen-Paap Wald statistic & 29.13 & & \\
\hline \multirow[t]{2}{*}{ Hansen J statistic } & & 0.987 & \\
\hline & & (p: 0.3205) & \\
\hline Regression & First Stage IV & IV & \\
\hline
\end{tabular}




\section{Appendix}

\section{Summary Statistics - Robustness Tests - Panel A}

This table depicts country-level averages of the variables used in the robustness tests and the instruments. Column (1) depicts the fraction of family firms from Faccio and Lang (2006). Column (2) and (3) respectively show the family services provided by the state, and the tax breaks for families as a percentage of GDP for 2007 from the OECD family database. (4) shows the gender wage gap for skilled workers from Olivetti and Petrongolo (2011, Table 2 column 2). A society's average values as defined by 3 items from the WVS (waves 4 and 5) are listed in the remaining columns. (5) the response to Q D057, scaled between 1-4 but reversed so that the highest answer fully agrees with the statement that "Being a housewife is just as fulfilling as working for pay". This variable is also used in Alesina et al. (2010). (6) is the response to Q A029, a dummy variable that holds the value of one if the respondent thinks child independence is important, (7) the response to Q E233-the statement that "women's rights" are an "essential characteristic of democracy"-scaled between 1 - 10, with 10 being the highest value. Wave 4 values are averaged at the country-level and matched to 2001-2004 data. The remaining data is matched to wave 5 data. Instruments are Alternative Employment Contracts ('index_altern12' from Botero et al. (2004)) and Latitude ('lat_abst' in LaPorta et al. (2004)), which is the absolute value of the latitude of the country, scaled to take values between 0 and 1.

\begin{tabular}{|c|c|c|c|c|c|c|c|c|c|}
\hline & \multirow[t]{2}{*}{ FF-FL } & \multicolumn{2}{|c|}{$\begin{array}{l}\text { Family } \\
\text { Benefits }\end{array}$} & \multirow{2}{*}{$\begin{array}{r}\text { Wage Gap } \\
\text { Skilled }\end{array}$} & \multicolumn{3}{|c|}{ World Value Survey } & \multicolumn{2}{|c|}{ Instruments } \\
\hline & & Services & $\operatorname{Tax}$ & & $\begin{array}{c}\text { Women } \\
\text { housewife }\end{array}$ & $\begin{array}{c}\text { Child } \\
\text { indepen- } \\
\text { dence }\end{array}$ & $\begin{array}{c}\text { Women } \\
\text { need same } \\
\text { rights }\end{array}$ & $\begin{array}{c}\text { Alt. } \\
\text { Employ. } \\
\text { Contract }\end{array}$ & Latitude \\
\hline & (1) & $(2)$ & $(3)$ & (4) & (5) & (6) & (7) & (8) & (9) \\
\hline Australia & & 0.65 & 0.36 & & 2.92 & 0.63 & 9.21 & 0.500 & 0.300 \\
\hline Austria & 52.8 & 0.45 & 0.04 & 2.82 & & & & 0.500 & 0.524 \\
\hline Belgium & 51.5 & 0.95 & 0.58 & 5.64 & & & & 0.750 & 0.561 \\
\hline \multicolumn{10}{|l|}{ Bermuda } \\
\hline Canada & & 0.16 & 0.42 & 2.37 & 3.08 & 0.58 & 9.14 & 0.500 & 0.667 \\
\hline Denmark & & 1.80 & 0.00 & 4.43 & & & & 0.500 & 0.622 \\
\hline Finland & 48.8 & 1.34 & 0.00 & -0.53 & 3.15 & 0.69 & 9.17 & 0.844 & 0.711 \\
\hline France & 64.8 & 1.66 & 0.72 & 6.70 & 2.56 & 0.38 & 8.62 & 0.688 & 0.511 \\
\hline Germany & 64.6 & 0.75 & 0.88 & 12.48 & 2.34 & 0.76 & 9.13 & 0.750 & 0.567 \\
\hline Greece & & 0.39 & & 7.78 & & & & 0.906 & 0.433 \\
\hline India & & & & & 2.80 & 0.67 & 8.21 & 0.219 & 0.222 \\
\hline Ireland & 24.6 & 0.28 & 0.11 & 8.05 & & & & 0.500 & 0.589 \\
\hline Italy & & 0.75 & 0.00 & 3.68 & 2.59 & 0.58 & & 0.719 & 0.472 \\
\hline Luxembourg & & 0.47 & 0.00 & & & & & & \\
\hline Netherlands & & 1.38 & 0.85 & 11.81 & 2.65 & 0.64 & 9.06 & 0.500 & 0.581 \\
\hline Norway & 38.6 & 1.45 & 0.10 & & 2.69 & 0.90 & 9.36 & 0.500 & 0.689 \\
\hline Portugal & 60.3 & 0.44 & 0.17 & -2.17 & & & & 0.906 & 0.437 \\
\hline Spain & 55.8 & 0.71 & 0.24 & 10.19 & 2.54 & 0.35 & 8.91 & 0.906 & 0.444 \\
\hline Sweden & 46.9 & 1.86 & 0.00 & & 2.51 & 0.75 & 9.84 & 0.719 & 0.689 \\
\hline Switzerland & 48.1 & 0.32 & 0.14 & & 2.82 & 0.74 & 9.27 & 0.500 & 0.522 \\
\hline United Kingdom & 23.7 & 1.11 & 0.33 & 15.44 & 2.86 & 0.58 & 9.05 & 0.500 & 0.600 \\
\hline United States & & 0.55 & 0.53 & 10.36 & 3.10 & 0.54 & 8.58 & 0.500 & 0.422 \\
\hline
\end{tabular}




\section{Summary Statistics - Robustness Tests - Panel B}

This table shows the same variables as described in the Panel A, averaged over all countries. Norway is excluded.

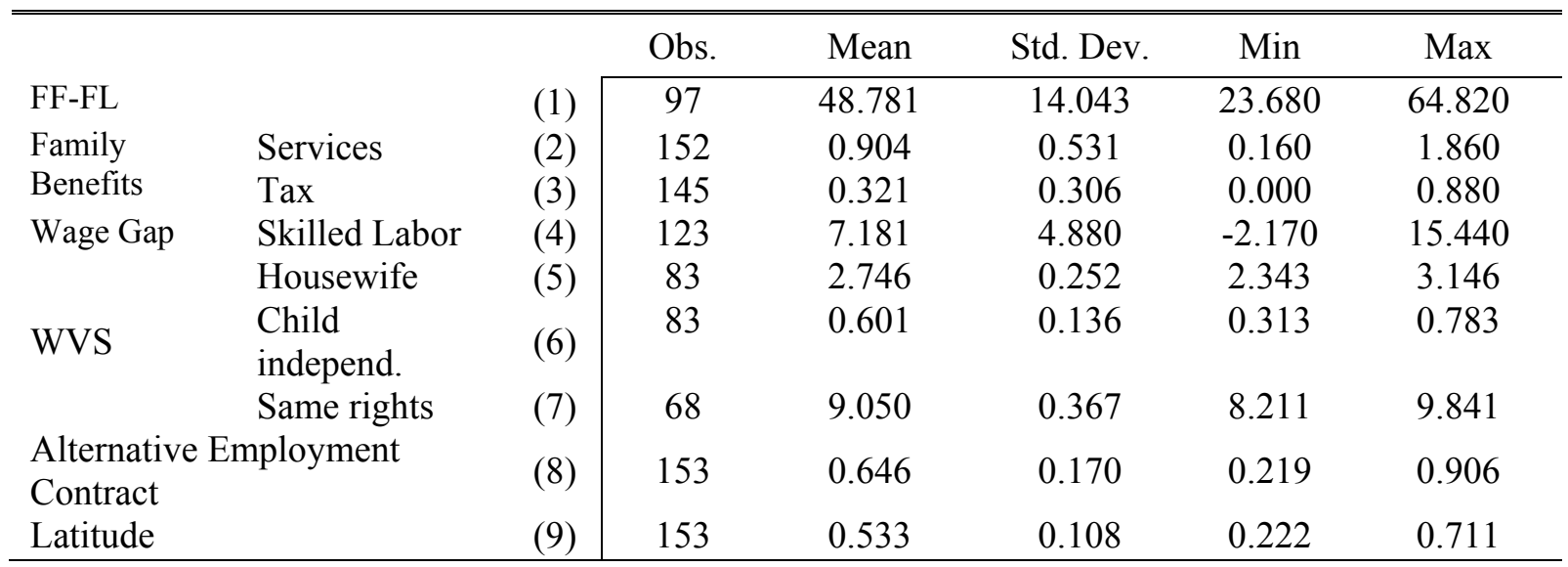

